\title{
Microbial Diversity: The Gap between the Estimated and the Known
}

\author{
Luciana Cristina Vitorino * (iD) and Layara Alexandre Bessa \\ Laboratory of Agricultural Microbiology, Goiano Federal Institute, Rio Verde Campus, \\ Rio Verde GO 75901-970, Brazil; layara.bessa@ifgoiano.edu.br \\ * Correspondence: luciana.vitorino@ifgoiano.edu.br; Tel.: +55-64-36205600
}

Received: 27 April 2018; Accepted: 11 June 2018; Published: 13 June 2018

\begin{abstract}
The ecological and biotechnological services that microorganisms provide to the planet and human society highlight the need to understand and preserve microbial diversity, which is widely distributed, challenging the severity of certain environments. Cataloging this diversity has also challenged the methods that are currently used to isolate and grow microorganisms, because most of the microbiota that are present in environmental samples have been described as unculturable. Factors such as geographic isolation and host preference also hinder the assessment of microbial diversity. However, prejudiced historical practices, including the prioritization of some species of microorganisms merely because they cause diseases, have long shifted research on fungi and bacteria towards medically relevant microorganisms. Thus, most microorganisms that inhabit the planet are still unknown, as is the potential of these species. Current estimates allow us to predict that the diversity of microorganisms that are present in the various terrestrial ecosystems is enormous. However, understanding this diversity is a challenge for the future of microbial ecology research.
\end{abstract}

Keywords: ecological diversity; non-ubiquitous microorganisms; unculturable microorganisms

\section{Biodiversity of the Planet}

Biodiversity, or biological diversity, describes the number, variety, and variability of living organisms, thus reflecting the biological heterogeneity of individuals present in natural ecosystems. Biodiversity may be described in terms of genes, species, and ecosystems, corresponding to three fundamental and hierarchically related levels of biological organization [1] that are present everywhere in the world, including tropical and temperate forests, tundra, deserts, and the ocean surface and subsurface, even in places previously considered uninhabitable by any life form, such as the polar ice caps and thermal or sulfurous springs.

An estimated 130 animal and plant species become extinct every day, although such estimates are still clearly unknowable for microorganisms. In 1992, the United Nations took note of these marked species extinction rates and created the Convention on Biological Diversity (United Nations 1992). This convention labeled biodiversity as worthy of preservation, both on land and at sea, but considers that biological diversity should be preserved not only for ethical reasons but also for the key ecosystem functions and services provided [2]. In this context, the important ecological functions exercised by microbiota, as described by the classical theory of the microbial loop [3,4], or the excellent services provided by microbiota to society, such as fermentation, antibiotic synthesis, or biological nitrogen fixation, render the knowledge and protection of microbial biodiversity an important issue in discussions involving the maintenance of the genetic resources of the planet.

Currently, it is impossible to determine the number of living organisms inhabiting the planet. However, a bold project involving American research societies aims to overcome this problem through the creation of the Systematics Agenda 2000 (SA2K), a 25-year, intensive international 
program designed to discover, describe, and inventory global species diversity and to summarize the resulting data into a predictive classification and develop an information system for data storage and analysis $[5,6]$. The data generated should also enable an assessment of species extinction risks. Considerable progress has already been made by SA2K in species discovery and documentation, with accelerated rates of taxonomic descriptions for some taxa (e.g., [7]), particularly those benefiting from funded research projects (e.g., the National Science Foundation's Planetary Biodiversity Inventory projects). However, despite these advances, much remains to be done in terms of discovering and documenting the biodiversity of terrestrial ecosystems and oceans (e.g., [8]). Therefore, the Systematics Agenda 2020 (SA2020) was proposed, which emphasizes the SA2K missions and broadens the focus to gaining an understanding of the evolutionary mechanisms that explain the origin, maintenance, and loss of biodiversity [9].

Undeniably, long before the Systematic Agendas were implemented, the collection of biodiversity data had already become a common concern of humankind. For example, the number of plants and animals described in the 10th edition of Systema Naturae (1758), written by the famous taxonomist Carolus Linnaeus, already totaled 9000 species. In another famous work, Peter M. Hammond, from the Natural History Museum of London, calculated the number of new species of birds described between 1978 and 1987 and showed that it increased at an average rate of $0.05 \%$ per year. Similarly, the number of described species of insects, arachnids, fungi, and nematodes increased at rates of 0.8 , $1.8,2.4$, and $2.4 \%$ per year, respectively. The differences between these values reflect only the size of the workforce, that is, the number of taxonomists dedicated to one group or another [10].

Although the total biodiversity of the planet has not been described, we work with predictions of biodiversity. The first estimates suggested the existence of approximately 3 million species in the world [11], but an enlightening study by Terry L. Erwin [12] showed that this number could be much higher. Considering only the diversity of beetles living in tropical tree crowns, estimates indicated that the number of insect species alone could range from 3 to 6 million. This suggested that the global number of species living in terrestrial ecosystems could reach 10 million [13] or up to 15 million, according to some extrapolations [14]. May [11] proposed an interesting relationship between the body size of individuals in animal groups and the number of existing species. Accordingly, because mammals have the largest body sizes in nature, their group has the lowest number of species. According to Reid and Miller [15] or Reid [16], there may be approximately 4000 species of mammals, 9000 species of birds, 6300 species of reptiles, 4200 species of amphibians, 19,100 species of fish, $1,000,000$ species of invertebrates, and 250,000 species of vascular plants worldwide. Among these groups, the rate of extinction is higher in birds (113 extinctions since 1600) and vascular plants (384 extinctions since 1600).

In addition to estimating how many species inhabit the planet, we are also focused on identifying where these species live. Presumably, close to 1.2 million species inhabit the tropical region of South America, and 1.0 million species are present in Africa. Conversely, it is estimated that only 200,000 species are present in North America and Europe [14]. Obviously, the annual loss of vegetation caused by changes in land use, particularly in tropical forests, has been the primary cause of biodiversity loss [17-19]. Currently, few tropical forests actually remain undisturbed, whereas the number of forests degraded by logging and by repeated fires, as well as the number of secondary forests and plantations, is rapidly increasing [20].

As estimated above, the tropics, because of their intrinsic characteristics, including high humidity and heat, have been recognized for concentrating the greatest species diversity on the planet. More than two thirds of terrestrial vertebrates live in tropical rainforests. Species diversity is also higher in the tropics among several other taxa, such as vascular plants and arthropods, as well as in other habitats, including freshwater and marine ecosystems [21]. High-diversity tropical forests exist on three continents and are concentrated in rainy plains. The highest species diversity occurs in the forests of the northwest region of South America. Tree and liana species richness is highest in the Amazon, but that of non-arboreal species is highest in the northern Andes and southern Central America, suggesting 
that conservation should be a priority for these areas [22]. However, according to Myers et al. [23], approximately $44 \%$ of all species of vascular plants and $35 \%$ of all species in four groups of vertebrates are confined to 25 hotspots that cover only $1.4 \%$ of the Earth's land surface. Conservation efforts should therefore focus on these hotspots, given the high proportion of endangered species that they support. Data on biodiversity in marine ecosystems are even more obscure. Approximately 250,000 [24] to 274,000 [25] marine species, including 110 mammals, 16,475 fish, 7000 echinoderms, 44,950 crustaceans, 12,000 annelids, 52,525 mollusks, 15,000 platyhelminths, 10,000 foraminifera, and others may have already been described. However, these marine biodiversity estimates have differed widely among studies (e.g., [10,11,24,26-28]). Approximately 1635 marine species are described every year; however, a key question underlying these discoveries remains unanswered: How many of these species really are new species and how many are synonymous? Discoveries of synonymous species may account for 10 to $20 \%$ of all new species described in marine ecosystems [29].

Thus, species classification and naming has not lost its historical complexity, because the species concept itself is still flawed. The following questions remain unanswered: How phenotypically or genetically different should an individual be from another to be considered a different species? Should a phenotypic difference be considered a determinant of a new species because it may result from a response to the environment? Does the occurrence of hybridity actually characterize interspecific crosses? Lastly, how much does our incomplete notion of the species concept affect the generation of ever-increasing diversity indices?

\section{Microbial Diversity: What Do We Have?}

Microbial diversity comprises the variety that is observed within highly genetically distinct groups, namely, bacteria, archaea, cyanobacteria, fungi, and viruses. Furthermore, the discovery and understanding of the diversity of microbial communities, that is, the number of species and their relative abundance, is an ecological priority. Locey and Lennon [30] used scaling laws to estimate global microbial diversity and predicted that the Earth is home to more than 1 trillion $\left(10^{12}\right)$ microbial species (Figure 1).

Considering this prediction, microbial biodiversity is apparently larger than expected by other researchers. For example, May [11] imagined that unicellular species, including species of the kingdom Monera (Domains Bacteria and Archaea) and eukaryotes of the kingdom Protista, would account for only $5 \%$ of all species on the planet, while fungi and plants would account for $22 \%$ of the existing species diversity, and animal diversity would actually be the highest, accounting for more than $70 \%$ of all living species. According to these estimates, prokaryotes would only account for a minute share of global biodiversity, but a study by Torsvik et al. [31] shows that there are likely millions of species in the Bacteria and Archaea domains, and that prokaryotic diversity in soils and sediments, estimated at $10^{9}$ individual bacteria per gram of soil (10,000 species), is higher than that in aquatic environments. However, it is not possible to understand the relationship between the vast reservoir of species diversity observed in soils and that in marine and lacustrine environments. Following the same strategy, Gans et al. [32] predicted that $1 \mathrm{~g}$ of soil may contain more than 1 million distinct bacterial genomes, radically surpassing the estimates of Torsvik et al. [31]. In 2007, Roesch et al. [33] used species diversity estimators and obtained 52,000 operational taxonomic units (OTUs) per gram in samples from four different soils, with Bacteroidetes, Betaproteobacteria, and Alphaproteobacteria being the most abundant bacterial groups in the four soils tested. However, Bouchet [29] studied marine diversity and predicted that 4800 bacterial species inhabit the oceans; this number is higher than that estimated for any other group of marine organisms. Furthermore, approximately 1000 cyanophytes and 500 fungal species are also present in marine environments. It is unclear, however, why the marine diversity of Archaea is apparently much lower than the marine bacterial diversity. Are Archaea more vulnerable to extinction or inherently less prone to speciation? [34]. 


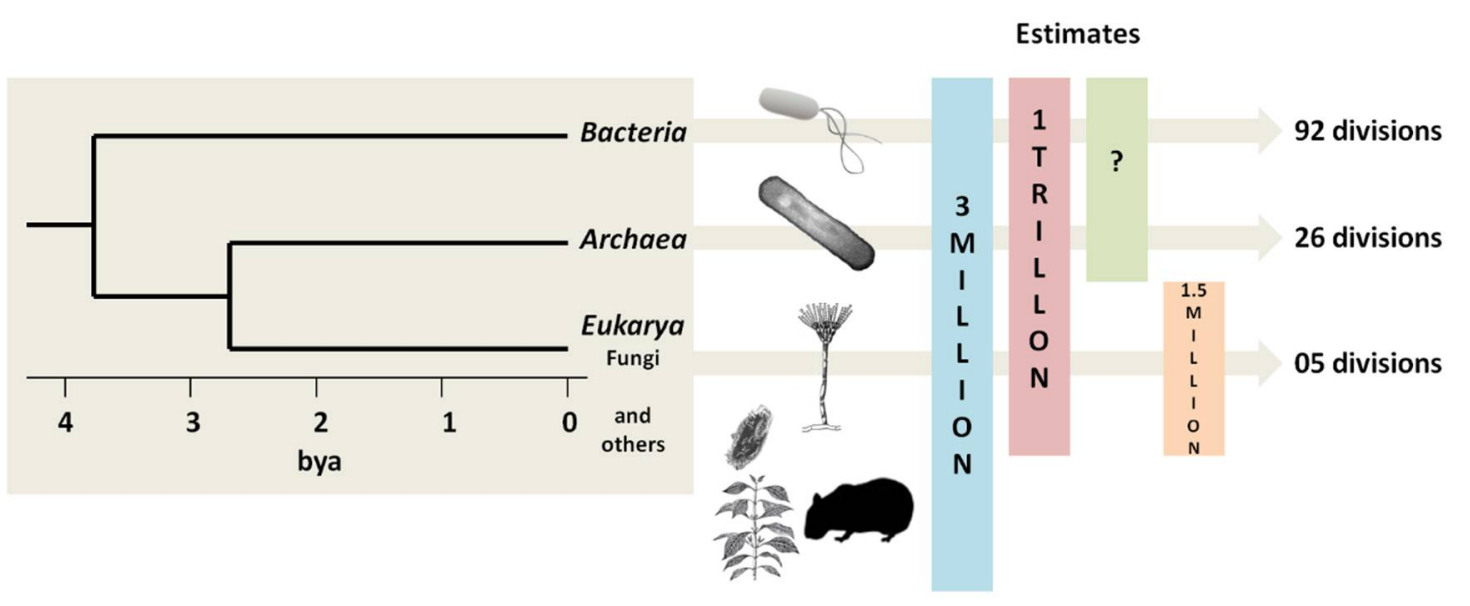

Figure 1. Estimates of the number of microbial species present in the three domains of life. Bacteria are the oldest and most biodiverse group, followed by Archaea and Fungi (the most recent groups). It is estimated that on the planet there are 3 million species of living organisms [11], but strangely, the number of microorganisms has been estimated at 1 trillion [30].

Currently, the number of validly published names of prokaryotic species is approximately 12,000 , although this number is clearly an underestimate, because more than 1.5 million animal species are known [35], and prokaryotic diversity is recognized as the highest on the planet. Nevertheless, the absolute species diversity of prokaryotes is widely regarded as unknown and unknowable at any scale in any environment, because the extent of such diversity is considered beyond practical calculation [36] (Figure 1). However, because not all species in a community need to be counted to estimate the number of different taxa in it, local and global prokaryotic diversity may be estimated, for example, with species abundance curves [34]. Thus, the diversity of prokaryotic communities may be related to the ratio of two measurable variables, the total number of individuals in a community, and the abundance of the most abundant members of that community. Using this approach, Curtis et al. [34] obtained the following estimates of small-scale bacterial diversity: in oceans-160 species per ml; in soils-from 6400 to 38,000 species per g; and in sewage-70 species per ml; and of large-scale bacterial diversity: in oceans-bacterial biodiversity may be higher than $2 \times 10^{6}$ species, whereas a ton of soil may contain $4 \times 10^{6}$ different taxa.

Over the last few decades, molecular-phylogenetic studies have allowed the development of a robust map of evolutionary diversification and showed that diversity is primarily microbial [37], because microorganisms have inhabited the planet for longer than any other group of living organisms. The first living organism is estimated to have appeared on the planet approximately 3.5 billion years ago. The lithotrophic metabolism of this first life form preceded phototrophy and organotrophy; thus, lithotrophic organisms became more widespread, phylogenetically and geographically, than other organisms that followed [38]. The consensus on primary metabolism is that molecular phylogenies need to recover the anaerobic lineages at the base of prokaryotic trees, with autotrophic, acetogenic, and methanogenic organisms being good candidates for the ancestral state of the physiology of bacteria and archaea [39]. The adaptive success of inorganic autotrophs, and the subsequent success of the first phototrophs, is shown by the current existence of purple sulfur bacteria, green sulfur bacteria, and cyanophytes. The first photosynthetic organism may have appeared on the planet approximately 2.5 billion years ago. The existence of photosynthetic life forms changed the entire primitive atmosphere through oxygen accumulation. As the atmospheric $\mathrm{O}_{2}$ concentration increased, another type of microbial metabolism emerged, aerobic heterotrophic metabolism, which became evolutionarily convenient. Accompanying the success and persistence of the abovementioned metabolisms, a large number of evolutionary diversifications emerged within the groups, resulting in the formation of two large domains, Archaea and Bacteria. Currently, we recognize more than 40 primary bacterial divisions 
and 12 or more divisions in Archaea $[37,40,41]$. Because these groups have been present on the planet longer than other groups of living organisms, Archaea and Bacteria may have diversified more and therefore potentially harbor the greatest biological diversity. This is suggested by a new version of the tree of life produced by Hug et al. [42], which shows the dominance of microbial diversification over other groups of living organisms. This tree was constructed considering 92 bacterial phyla, 26 Archaea phyla, and all five eukaryotic supergroups. However, another explanation for the existence of such a large number of bacterial species has been proposed: it is possible that the speciation rate in this group is higher than the extinction rate, leading to an increasing number of species over time [43].

In the early 1990s, Hawksworth [44] published a seminal paper that calculated estimates of the number of fungal species inhabiting the planet. The estimate of 1.5 million species was initially well accepted but currently seems rather conservative, since many potential habitats and locations have not yet been tested for the presence of these microorganisms [45]. More recent studies using molecular data have reported more optimistic estimates. For example, O'Brien et al. [46] tested DNA samples from a soil microbial community in which the high species accumulation rate observed suggested the existence of 3.5 to 5.1 million species. The discrepancies between estimates led Hawksworth [47] to recommend using the phrase "at least 1.5 but probably up to 3 million" until some of the uncertainties are clarified.

Despite the high estimates of the number of fungal species on the planet, only 100,000 species of fungi are currently known [48], comprising isolates associated with living or dead biological material, such as symbionts, parasites, or saprobes. If we confirmed the existence of at least 1 million species of fungi, the challenge would be to know where the 0.9 million unknown fungi are. This task becomes even more complex when we consider the various functional traits observed within fungi. Would most unknown fungi be associated with roots in mycorrhizal associations? Would they be living in plant tissues endophytically? Or would they be associated with insects or algae? Or are they in unexplored habitats? It is also possible that the unexplored fungal diversity is part of the group of unculturable microorganisms.

The hypothesis that tropical regions harbor the greatest fungal diversity on the planet must still be tested; however, because experts confirm this hypothesis for other living organisms, it is also assumed to be true for fungi [49]. Gilbert et al. [50] assessed the diversity of polypore fungi in a tropical forest in Panama and observed a relationship between increased population density of host plants and increased fungal diversity. This relationship may explain why tropical forests, naturally denser than other forests, are the front-runners for habitats with the highest fungal diversity on the planet. The same effect was shown by Brundrett and Ashwath [51] in a study of arbuscular mycorrhizal fungi (AMF) in tropical rainforest areas in Australia, where they found an increase in the abundance of AMF spores in habitats with dense vegetation. Similarly, Schimann et al. [52] showed that vegetation cover has an important effect on the structure of fungal assemblages inhabiting the soil and leaf litter of Amazon forests. In a study conducted in French Guiana, this group identified associations between tree species and soil and leaf litter fungi, and this association explained up to $18 \%$ of the variation among the fungal communities sampled in the forest.

Fungal diversity is currently divided into four phyla, namely, the aquatic basal phylum Chytridiomycota, which has approximately 1000 known species [53]; the polyphyletic phylum Zygomycota, with just over 1000 described species [54]; the subphylum Mucoromycotina [54], which includes 300 species; the large phylum Ascomycota, with approximately 64,000 known species; and the phylum Basidiomycota, with 32,000 species [54-56]. In 2001, based on phylogenetic analyses of the small ribosomal RNA subunit, Schüßler et al. [57] introduced a new classification proposal for the kingdom Fungi involving the transfer of AMF from the division Zygomycota to the new division Glomeromycota, which is a sibling group of the clade comprising the divisions Basidiomycota and Ascomycota.

Regarding mycorrhizal fungi, estimates suggest the existence of approximately 50,000 species that form associations with approximately 250,000 plant species [58]. From 300 to 1600, fungal taxa may be associated with plants, forming arbuscular mycorrhizae, and these fungi belong only to the 
phylum Glomeromycota [59,60]. Regarding ectomycorrhizal fungi, Comandini et al. [61] conservatively estimated, based on bibliographic research, that the species richness of this group is approximately 7950 taxa distributed across 234 genera. These global diversity values, comprising Basidiomycota and Ascomycota fungi, were confirmed by Tedersoo et al. [62]. Orchidaceous mycorrhizal fungi, which are known to associate only with orchids, are widespread in the phylum Basidiomycota and may comprise approximately 25,000 taxa [58], whereas ericoid mycorrhizal fungi, which predominantly associate with members of the family Ericaceae, are primarily Ascomycota, with only a few described within Basidiomycota, and more than 150 taxa are estimated to occur within this group [63].

With respect to endophytic microorganisms, no estimates of the global number of species are available, perhaps because they are a group for which data are still scarce; however, in a study conducted in a tropical rainforest in Panama, Arnold et al. [64] isolated 418 morphospecies (347 genetically distinct taxa), suggesting hyperdiversity of the tropical endophytic community and a marked underestimation of the diversity of this group. Arnold and Lutzoni [65] compared endophytic communities along a broad latitudinal gradient from the Canadian Arctic to the lowland tropical forest of central Panama. They showed that the incidence, diversity, and host spectrum of endophytes increases from the Arctic to tropical sites. Furthermore, tropical plant species were dominated by a large number of endophytic species. Thus, they concluded that the leaves of tropical trees are biodiversity hotspots of fungal species, containing species that have not yet been recovered from other biomes.

Studies on species diversity in microbial communities usually depict local conditions, that is, they assess the microbial diversity of the endophytic community associated with roots or leaves of a specific plant species (e.g., [66,67]). Some studies have also assessed the effect of various factors, such as tissue type, plant developmental stage, and nutrient availability, on the diversity of communities (e.g., [68]). Evaluations of rhizospheric communities have followed the same pattern, reflecting highly specific conditions; therefore, no attempts to estimate the total number of endophytic or rhizospheric species that are present on the planet have been reported. The limited number of published studies on these communities is currently a limiting factor for the calculation of these estimates. For the same reason, we also lack such estimates for phosphate-solubilizing microorganisms, phytopathogen controllers, lignocellulolytic fungi, and other microbial groups.

\section{Why Do We Not Know Microbial Diversity Well?}

According to Pace [37], the primary reason for our poor understanding of the microbial universe is that microorganisms are individually invisible to the eye. The very existence of microbial life was only recognized slightly more than 300 years ago, which is relatively recent in the history of science. When the naturalist Antony van Leeuwenhoek used his primitive microscope, which had lenses that allowed a magnification of up to 300 times, he observed bacteria measuring 1 to 2 microns; however, the taxonomic techniques of the time, based only on morphology, could not be used to classify the organisms of the newly discovered universe. In the late nineteenth century, Robert Koch joined the staff of the Imperial Health Office in Berlin and perfected liquid culture media, developed by Klebs and Lister, and developed the pure plate culture technique [69]. Only then did microbial identification studies begin to be conducted.

Over the years, this approach has shown its limitations, because many microorganisms challenge standard culture methods. Recently, new microbial identification methods have become popular and are helping to change our perspective of microbial diversity. Notwithstanding, challenges still lie ahead, because many microorganisms have been shown to have a restricted geographical distribution and prefer specific habitats. 


\section{We Do Not See Microorganisms}

When May [11] predicted that unicellular organisms would account for only $5 \%$ of living species, attributing a very small share of global biological diversity to prokaryotes and a 70\% share of that diversity to animals, May based his predictions on data that had accumulated until that point. We must remember that microorganisms began to draw the attention of scholars only after the early works of Pasteur and Robert Koch in the late nineteenth century, who described the association of these microorganisms with diseases and proposed vaccination methods [70,71]. Until then, all systematics research was primarily focused on describing plants and animals. Moreover, in the 1970s and 1980s, we actually experienced a period of latency in microbiology in relation to the development of zoology and botany [72].

One of the great obstacles we face when studying microorganisms is the fact that, except for some sexual reproductive structures of fungi, such as ascocarps and basidiocarps, they are all microscopic, that is, we cannot see them with the naked eye, excluding colonies grown in Petri dishes or in special situations in nature. This requires using microscopy, often advanced microscopic methods, to study capsules, flagella, spores, or modes of reproduction. However, it should be noted that these techniques are not routinely available in all basic education schools worldwide, even though the laboratory is recognized as an important space in the establishment of the teaching-learning process [73]. This is especially true when seeking to understand scientific evidence, for which the development of experimental skills is regarded as essential [74]. Access to basic microscopy by biology students in schools in developing countries is even more crucial. Thus, how can we be drawn to study what we do not see? Is it possible that May's estimates are reflective of our interest in the study of fauna and flora, which sets aside knowledge of the "invisible to the naked eye"? In a study conducted to measure the interest of students in Biology, Prokop et al. [75] identified Zoology as the most popular topic.

This lack of contact with the microscopic universe by students may also contribute to the small number of microbiologists or researchers in the field entering the market annually.

\section{They Cause Diseases}

The confirmation of the microbial theory of diseases, attributed to the publication of Koch's postulates in 1876, placed microorganisms on the list of villains for several decades, because they were only observed from the perspective of human and animal health. This occurred despite the celebrated works of Sergei Winogradski and Martinus Beijerinck (late nineteenth and early twentieth centuries), who drew attention to the role of microorganisms in important ecological processes [76,77] (Figure 2). Indeed, the human body houses a high diversity of microorganisms. The microbiological communities living in our skin, mouth, esophagus, stomach, colon, vagina, and other organs (e.g., [78-81]) are designated the human microbiome [81]. Studies show that the intestine houses the largest number of microorganisms of the human body, and most of the 10-100 trillion microorganisms present in the gastrointestinal tract live in the colon. Despite the high number of microorganisms that interact with the human body, more than $90 \%$ of all bacterial phylogenetic types already described in the human microbiome belong to only two divisions of the bacterial domain: Bacteroidetes and Firmicutes [81].

Indeed, infection or the colonization of parts of the body rarely results in clinical signs of disease. On the contrary, when microorganisms live in equilibrium with the host, they can modulate the immune response, providing a source of cross-reactive antigenic material that activates self-reactive lymphocytes within the intestinal environment $[82,83]$. Furthermore, these microorganisms can be a barrier to the establishment of pathogenic microorganisms [84] and participate in the synthesis of vitamins and essential amino acids or in toxin degradation (e.g., $[85,86])$. These functional traits and many others have been described in recent years for the intestinal microbiome. For example, evidence suggests that the microbiome may affect the likelihood of diseases, such as diabetes and obesity [87]. 


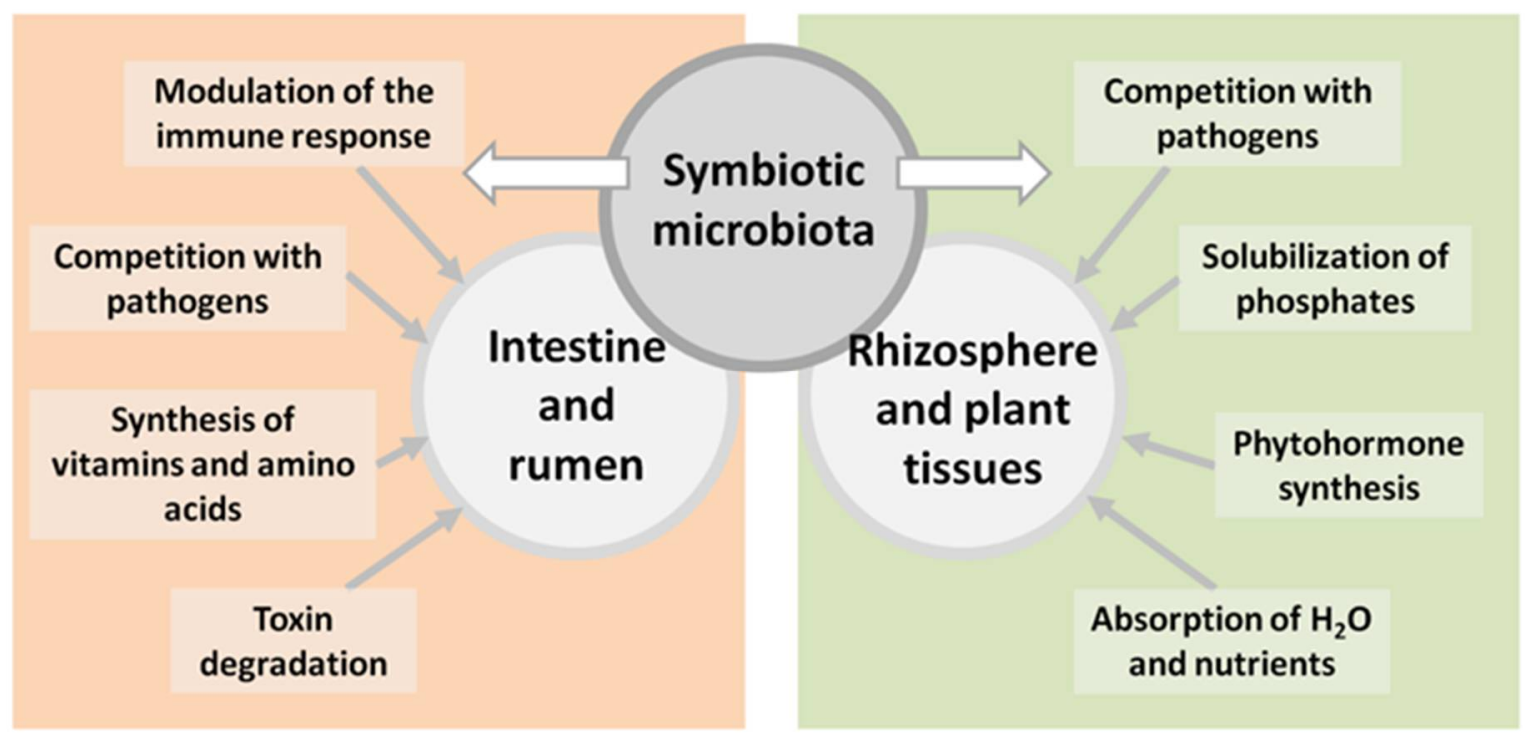

Figure 2. Functional roles played by the symbiotic microbiota in animals and plants, demonstrating the importance of the animal-microorganism and plant-microorganism relationships, which go far beyond the pathogenic role of some strains.

Although not all microorganisms that interact with the human or animal body are pathogenic, the popularization of this knowledge among professionals in the field alone is insufficient to break the historical pattern of exclusively relating microorganisms to contagious diseases. The same is true for phytopathogenic microbial species. In recent decades, most agronomic studies have focused on microorganisms that act as agricultural pests. However, considering the potential microbial diversity that inhabits the planet, few species are actually described as pathogenic for animals and plants. For example, the vast majority of phytopathogens initially inhabit soil and crop waste [88], and the primary phytopathogenic bacterial species belong to the genera Agrobacterium, Clavibacter, Erwinia, Pseudomonas, and Xanthomonas, while the primary fungal phytopathogens belong to the genera Aspergillus, Fusarium, Penicillium, Pythium, Rhizoctonia, Sclerotinia, Sclerotium, and Verticillium. This shows that most of the microbiota is related to functional roles, such as decomposition, plant growth promotion via endophytic or rhizospheric relationships, and symbiosis with the intestinal tract of animals and biomineralization in areas with high availability of ores, among others. However, the widespread historical perspective of the potential of microorganisms as disease agents may have discouraged ecologists, systematists, and taxonomists from researching new species of microorganisms, thereby limiting our knowledge on the number of microorganism species, despite the diversity within this group being potentially the largest on the planet, especially when considering both prokaryotes and fungi.

\section{The Primary Methods of Detection in Use Have Already Become Outdated}

Failures in processes of detection of microbial species corroborate the lack of knowledge about their diversity. Many unknown microorganisms may have already been sampled or even identified as part of widely defined groups due to crude morphological characterizations. Furthermore, other microorganisms that have been sampled and identified as new species may have not been described yet [49] due to the lack of technical expertise of researchers in performing detailed descriptions.

The following methods are currently available to identify microorganisms: preparation of pure cultures followed by morphological-anatomical and/or molecular identification, metagenomics, and isotopic characterization. The preparation of pure cultures is still a prerogative for in-depth classification of microorganisms, because these cultures have genetically and morphologically identical cells that can be used for morphoanatomy analyses or DNA extraction (Figure 3). 


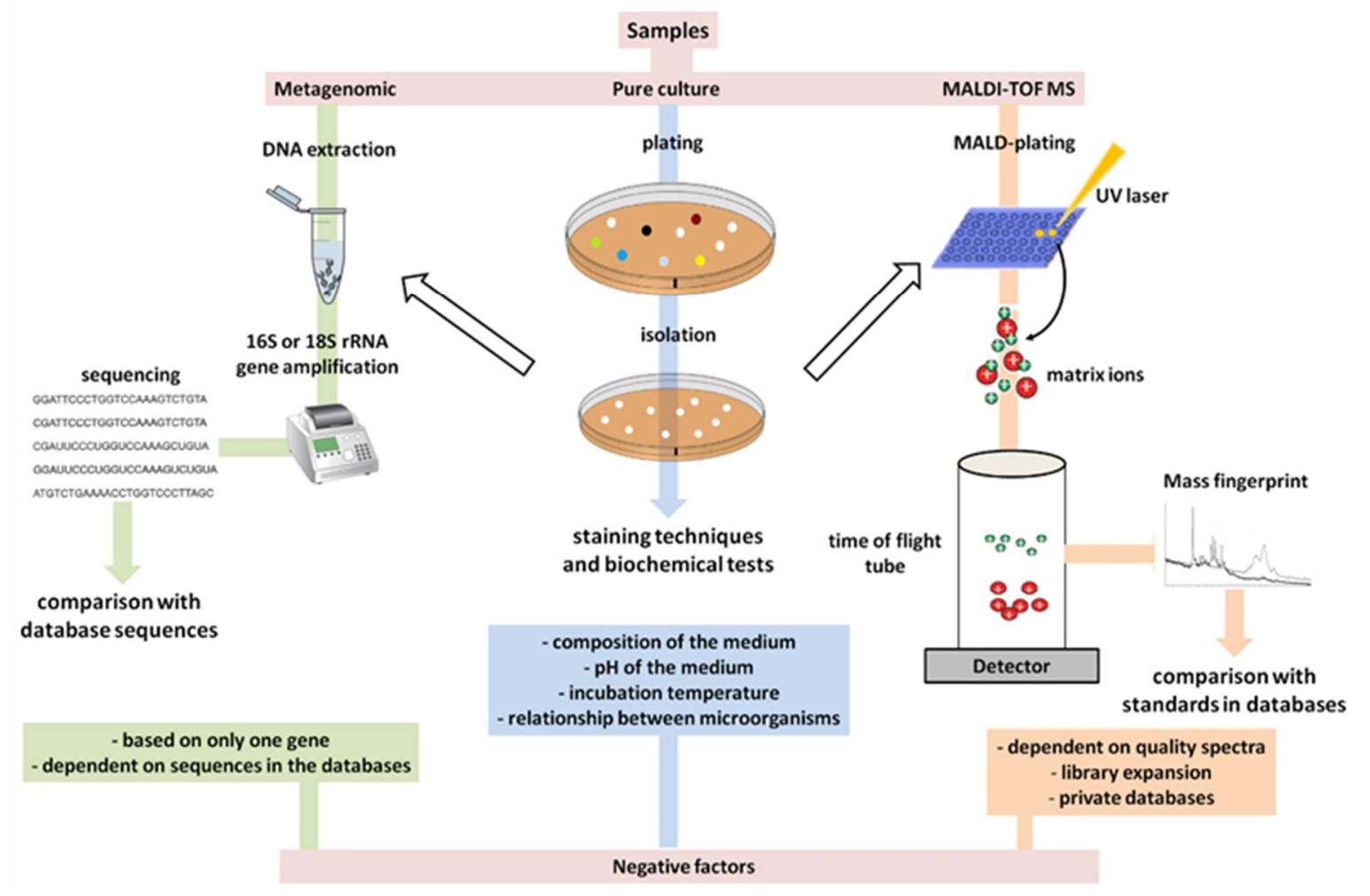

Figure 3. Description and aspects of methods currently available for microorganism classification. Microorganisms isolated from general samples can be identified by metagenomics, by pure culture combined with morphoanatomy analysis (staining techniques and biochemical tests), or by mass spectrometry.

In morphoanatomy analyses, we strictly analyze aspects of bacterial colonies, such as their color, shape, and consistency when grown in special media. For example, when bacteria of the genus Bradyrhizobium are grown in medium 79, they become white, have a mucosal consistency, and alkalinize the medium [89]. For fungi, we also analyze the growth rate and colony pigmentation to identify species. The classic Gram staining technique can be used to classify a bacterium as Gram-positive or Gram-negative, which allows us to characterize groupings and to collect data on cellular morphology, while biochemical tests help to characterize strains by identifying physiological characteristics. However, the wide metabolic diversity of bacteria, highly affected by the growth environment, may lead to erroneous species classifications. We also prepare microscopy slides for fungi, usually accompanied by special techniques, such as microculture. Special stains may help to visualize hyphae and reproductive structures, such as conidiophores and sporangiophores, as well as the shape of the spore, which is a fundamental structure for the taxonomy of fungi.

However, classifications based on morphoanatomy are highly dependent on the microbiologist's experience, requiring refined observation and extensive knowledge of the microscopic morphological structures of fungi. Therefore, morphoanatomical identification usually requires confirmation by molecular identification. Because microscopy-based identification is time consuming and laborious, researchers commonly choose to proceed with the molecular identification, even without collecting morphological data on the species. The molecular identification of microorganisms is performed based on the amplification of the 16S rRNA gene for bacteria, cyanobacteria, and archaea (e.g., [90-92]), and on the $18 \mathrm{~S}$ and/or $28 \mathrm{~S}$ rRNA gene for fungi (e.g., [93,94]). The sequences of these genes are used in microbial taxonomic studies for several reasons: the 16S rRNA gene is found in almost all bacteria, cyanobacteria, and archaea, often as a multigene family or within operons; its function has not changed over time, suggesting that random changes in sequences are a more accurate measure 
of time (evolution); and the size of this gene, approximately $1500 \mathrm{bp}$, is large enough for computing purposes [95]. Likewise, the $18 \mathrm{~S}$ rRNA gene is conserved and widespread among eukaryotes [96] and is approximately $1800 \mathrm{bp}$ long [97].

In molecular identification, the sequences of ribosomal regions are compared with other sequences deposited in databases. Thus, the microorganism is identified according to the percentage of the nucleotide sequence similarity/identity with database sequences, considering the best "score" and "e-value" combination. The relative simplicity of the molecular approach allowed for an exponential increase in the number of recognized taxa and the rapid expansion of the collection of available rRNA sequences for taxonomy, ecology and phylogenetic analyses. In this context, molecular identification rapidly outperformed the morphoanatomical identification of isolates or, in combination with morphoanatomical identification, generated more accurate data on microbial identification. The diversity of rhizospheric fungi, for example, was based for many decades on the number of colonies growing in Petri dishes from diluted samples of rhizospheric soil. Similarly, the diversity of AMF was, and still is in some cases, traditionally estimated based on spore counts (e.g., [98-100]). However, these methods may lead to erroneous estimates. For example, the composition and $\mathrm{pH}$ of culture media, as well as the incubation temperature, or even the ratio between microorganisms in the culture environment, may not be equally favorable to the growth of all microorganisms present in the soil sample in question. Moreover, mycorrhizal spore production is controlled by many factors, and no direct relationship may occur between the spore population in the soil and that in the colonized roots. Using molecular techniques, AMF or even endophytic fungi may be directly identified in plants by polymerase chain reaction (PCR) to amplify specific AMF sequences, such as those of ribosomal RNA genes [101].

With the possibility of collecting genotypic data, the taxonomy of Bacteria and Archaea became polyphasic, because these data have been extensively combined with phenotypic and chemotaxonomic data. We are currently experiencing a rapid increase in the number of descriptions of new taxa, especially at the species level. We have also noted many cases of demarcation of prokaryotic species and even attempts to develop algorithms for the demarcation of "ecotypes" [102]. The analysis of genomic data also provides a more complex picture of phylogeny within groups and reveals a series of additional links, such as those recently revealed between Archaea and Eukarya [103]. Alternatively, next-generation sequencing (NGS) provides a fast and inexpensive approach to the whole-genome sequencing of microbial strains. Efforts are now focused on obtaining complete genomic sequences of type strains so that genomics and computational advances can increase the credibility of the taxonomy of Bacteria and Archaea [35].

In addition to genomics and gene sequencing of microbial isolates, metagenomics has emerged as a method for revealing the diversity hidden in environmental samples. Although part of the microbial diversity is lost when cultivation methods are used [104], the sequencing of the $16 \mathrm{~S}$ and $18 \mathrm{~S}$ rRNA regions of microorganisms present in natural samples alternatively allows for the direct identification of genera and/or species without requiring isolation. Thus, metagenomics has been recently used to describe the composition of intestinal, ruminal, and even respiratory tract microbiomes (e.g., [105-107]) Metagenomics has also been used to describe microbiomes found in fermentation systems, such as those involved in rice wine production, or in soda lakes (naturally saline lakes with alkaline $\mathrm{pH}$ ) $[108,109]$, or even those found in natural ecosystems, such as prairie soils, deserts, and rainforests [110], in addition to deep hypersaline or freshwater lakes [111,112].

Thus, with the advancement and popularization of molecular techniques, a high number of studies on the composition of microbial communities can be conducted or are in progress. However, most published studies address only the resolution of phyla, genera, and, at best, species (e.g., [113-116]). In the future, strategies using several polymorphic loci may help define intraspecific variability, thereby assessing diversity at a finer scale of resolution. Sanders and Rodriguez [117] proposed combining the use of such markers with experimental studies on AMF diversity to help elucidate intraspecific diversity in plant communities. Thus far, however, when the challenge remains to understand the species and 
phyla present in the various ecosystems and the interspecific microbial relationships, studies remain highly focused on prospecting species. In addition, studies have provided evidence of microbial endemism [118] and also of a spatial pattern of microbial diversity [119]. These inferences have resulted from molecular approaches that allow a more comprehensive view of microbial diversity [47]. However, this diversity must be closely analyzed from the standpoint of closely related but ecologically different species to understand the hidden factors underlying the high diversity observed within some groups and habitats.

Although molecular methods are faster and more accurate than conventional methods of microbial taxonomy in determining the composition of communities, great progress in the rapid identification of microorganisms has been made by the use of the proteomics technique MALDI-TOF MS (matrix-assisted laser desorption ionization time-of-flight mass spectrometry), which enables diagnosis within 5 to $15 \mathrm{~min}$ [120]. This technique consists of the use of mass spectrometry, in which the microbial colony is initially placed on a plate with a polymeric matrix (Figure 3). This biological material is then irradiated with a laser that vaporizes the sample, ionizing several molecules that are aspirated into a vacuum tube and led to a detector. Different molecules have different times of arrival at the detector (time of flight), which are plotted onto graphs, generating several peaks. A specific graph is constructed for each bacterial or fungal species, and a computerized database interprets and provides fast identification results [121]. MALDI-TOF MS is a highly precise method for bacterial classification and identification $[122,123]$, but has as limitation, as it can be applied only to microorganisms already cultivated. The approach may identify low-abundance bacteria, even in mixed flora, although the identification performance of MALDI-TOF MS depends on the number of available mass spectra with the quality required for identification [124]. The expansion of species libraries and the increase in the number of species spectra are crucial for maximizing identification efficiency [125]. This expansion is occurring as the technique becomes popular. However, a disadvantage of this technique is the private nature of these databases. This is not the case with nucleic acid databases, which are public and therefore easily accessible. Notwithstanding, this technique is already the standard method of identification of microorganisms grown in most clinical laboratories in Europe and has excellent popularization prospects in the Americas and in Asia [126].

Although molecular and ionization methods have shown better results than conventional methods of microbial taxonomy, they have not been promptly adopted by all laboratories working on the isolation and identification of microorganisms, primarily due to the resources required to equip laboratories and train professionals on molecular techniques or spectrometry. MALDI-TOF MS has become popular for the generation of rapid diagnoses, especially in the identification of pathogenic bacteria, such as members of the genera Bacillus, Burkholderia, Brucella, Francisella, and Yersinia (e.g., $[127,128])$. Some protocols have also been adapted to directly identify fungi from clinical samples [129], but further adaptations are required for retrieval of data from underexplored microbiomes, such as rhizospheric, endophytic, or mycorrhizal microbiomes. The extension of databases will also result in greater applications for the identification of microorganisms in environmental samples [130], and the outlook is interesting, because some attempts have already been made. For example, Martínez-Molina et al. [131] used MALDI-TOF MS to identify Rhizobium strains associated with Pisum sativum L. roots, and the method was found to be able to differentiate species that were very closely related genetically and were indistinguishable based on 16S rRNA gene analysis. Urquiza et al. [132] used spectrometry to identify bacteria present in the rhizosphere of apple plants grown in soil with a high concentration of mercury, while Avanzi et al. [133] assessed the use of MALDI-TOF MS as a microbiota-monitoring method for sites contaminated with copper. In the future, spectrometry and gene sequencing should be used complementarily to assess a larger contingent of microbial diversity. The swiftness of the MALDI-TOF technique, coupled with polymorphism data detected by molecular methods, will help elucidate the diversity of microorganisms on the planet and the diversity between communities and microbial populations. 


\section{Many Are Neither Cosmopolitan or Culturable}

Throughout the history of microbial ecology, the population size of bacteria in soils, sediments, and natural waters has been assessed by preparing cultures of microorganisms and counting the number of colonies growing on nutrient agar plates. Using this method, a large number of colonies can typically be obtained from these samples. Therefore, the microbiota was generally considered ubiquitous [134]. The tenets of microbial cosmopolitanism were that large population sizes and short generation times always result in high dispersion rates of microorganisms $[119,135,136]$. However, evidence shows that some taxa respond to limitations in dispersal by geographically isolating themselves at local and/or global scales (e.g., $[137,138]$ ), suggesting that not all microorganisms are able to spread globally. Microbial distributions may be related to the Baas-Becking hypothesis, that is, "everything is everywhere, but the environment selects" [139], although recent studies have shown that many species exhibit geographical distribution patterns at different scales $[140,141]$. These restrictive variations can result from both environmental filtration and dispersal limitation [140]. Geographical isolation may result from the existence of barriers to the flow of organisms [142] that lead populations to diverge through local adaptation or random genetic drift. Alternatively, however, this may simply reflect patterns of geographical distribution of specific local environmental conditions [143], such as climatic or habitat characteristics. The role of dispersal barriers in the biogeography of microorganisms is therefore controversial. Conversely, large population sizes and resistant life stages (e.g., spores) make microorganisms less susceptible to stochastic extinction events $[119,136]$, corroborating the theory of microbial cosmopolitanism.

However, evidence of microbial cosmopolitanism is often mixed and confused with artifacts resulting from gross taxonomic resolutions and subsampling. The identification of endemic microorganisms in true geographical isolation, such as in extreme environments (e.g., thermal springs, salt lakes, and hot and cold deserts worldwide), is strong evidence against the theory of microbial cosmopolitanism, since microbial distribution is non-random under these conditions [144-148]. Therefore, the difficulty lies in assessing the determinants of microbial geographical distribution, be they historical evolutionary events (e.g., geographical barriers) or contemporary ecological environmental factors [142].

Furthermore, differences between distribution environments (soil or water) have led marine and freshwater microbiologists to believe in the ubiquity of all microbial taxa (e.g., [149-151]), whereas those that study soils disagree with this concept. Noguez et al. [152] examined the scale of prokaryotic diversity in soils and compared it with the biogeographic patterns of other groups. They found well-structured species assemblages that allowed them to reject the hypothesis of ubiquitous dispersal and to suggest a complex biogeography similar to that described for terrestrial vertebrates.

The fact is that the demonstrated, non-random distribution of many microbial taxa can be viewed from two perspectives: as a determinant of the generation of endemisms, and consequently, of diversity, insofar as microorganisms restrict their distributions in response to environmental stimuli or to habitat characteristics; or as a limiting factor when assessing microbial diversity, because microorganisms should be assessed as a function of their habitats, thus requiring the development of new strategies to grow and isolate microorganisms. A problem is that although thousands of microbial strains have already been cultivated and successfully described, evidence suggests that they account for only a small fraction of the overall microbial diversity. This is because many microorganisms that are ubiquitously and abundantly present in the environment are difficult to cultivate axenically [153], precluding their morphological identification. Therefore, the quantification of microbial diversity has been a technical challenge. For example, independent cultivation approaches have demonstrated that the microbial diversity of soil and rhizosphere microbiomes is highly underestimated. Next-generation sequencing methods have shown that only a minority (up to 5\%) of the bacteria in these microbiomes have been cultivated using the currently available methods and that a considerable proportion of the bacterial phyla detected using these technologies do not yet have any cultured representatives [154]. 
Using culture techniques for seawater, for example, researchers have observed that the size of the culturable prokaryotic population is a few hundred cells per milliliter; however, these values are negligible, because millions of cells per milliliter, or per gram of soil or sediment, are observed by electron and/or epifluorescence microscopy [155]. Indeed, less than $1 \%$ of bacteria of natural communities can be cultivated in the laboratory, which has led to historical underestimations of microbial diversity and has affected our view of microbial communities [43]. For a long time, microbial ecology had to curb its efforts to assess the microbial diversity of different ecosystems, simply because many microorganisms do not grow on plates.

It is estimated that approximately $99 \%$ of all species occurring in outdoor environments are unculturable (they do not grow under laboratory conditions) [156]. For example, most of the approximately 1000 species in the phylum Chytridiomycota have not yet been grown in culture media [53]. Because they believed that non-isolated microorganisms could have high biotechnological potential, Ling et al. [157] developed methods to grow unculturable organisms in their natural environment using specific growth factors, such as siderophores. In this experiment, the authors were able to isolate several metabolites of interest, including a new antibiotic. Therefore, the methods of assessing microbial diversity must evolve beyond isolation on agar plates. New genetic technologies, especially metagenomics, have emerged as efficient alternatives to explore microbial genomes and to expand our understanding of most microbial species on Earth. This method allows us to assess the microbial diversity contained in environmental samples, which is groundbreaking, especially for species with low relative abundance, but does not allow us to assess microbial metabolites, which still depend on the use of plates and culture media.

\section{They Are Habitat Specialists, and We Have Not yet Evaluated All Habitats}

Despite the microbial ubiquity theory, many microorganisms have been described as habitat specialists; thus, their distribution is more restricted, which makes it difficult to sample these species because they tend to be rarer. Logares et al. [158], for example, showed that specialized bacteria are present at the extremes of a salinity gradient, that is, freshwater lakes (salinity 0 ) and hypersaline lakes (salinity 100). In addition, Juutilainen et al. [159] evaluated the habitat specialization of 77 saprophytic fungal species in different boreal forest types and observed that a high level of specialization was associated with deciduous forest types.

The response of microbial communities to long-term environmental changes is poorly understood, and it is not clear how dispersal can impact the diversity of local microbial communities, although habitat generalists may be more likely to disperse in response to environmental changes. Selection in stable environments should lead to the evolution of specialists, whereas selection in periodically varying environments should lead to the evolution of generalists [160] (Figure 4). For example, Comte et al. [161] showed that the percentage of freshwater taxa declines with increased salinity, whereas marine taxa readily increase from freshwater sources, suggesting that this response is driven by the increase in habitat generalists normally found in marine systems. Environmental changes resulting from pollution and/or urbanization have led to the replacement of specialist nectar yeast species by generalist yeasts, because the latter are less dependent on pollinators for dispersal between flowers [162]. Thus, studies have suggested that beta diversity along environmental gradients can be adequately described considering only generalist taxa [163].

The presence of habitat specialists in ecosystems may also be affected by interactions with local microbiota. Dispersed bacteria adapt to new environmental conditions by competing with the local resident communities [164]. In the presence of a local resident community, the relative abundance of generalists increases, suggesting that competitive interactions between local and immigrant taxa could function as an environmental filter for microbial dispersion.

In biotrophic species, such as mycorrhizal and endophytic fungi, host preference can drastically affect diversity, since species occurrence is limited to the occurrence and dispersal of the host. Accordingly, numerous studies have shown that host preference or recurrence is important for 
the formation of biotrophic [165-168], lignolytic [50], and pathogenic [169] fungal communities. Thus, the description of all microbial diversity apparently requires an assessment of all hosts and habitats. Large differences have already been described between the diversity and the population structure of AMF in different temperate ecosystems [170,171]. These studies also showed non-random associations between host plants and mycorrhizal fungi. However, the question remains: When will we finally be able to analyze all habitats?
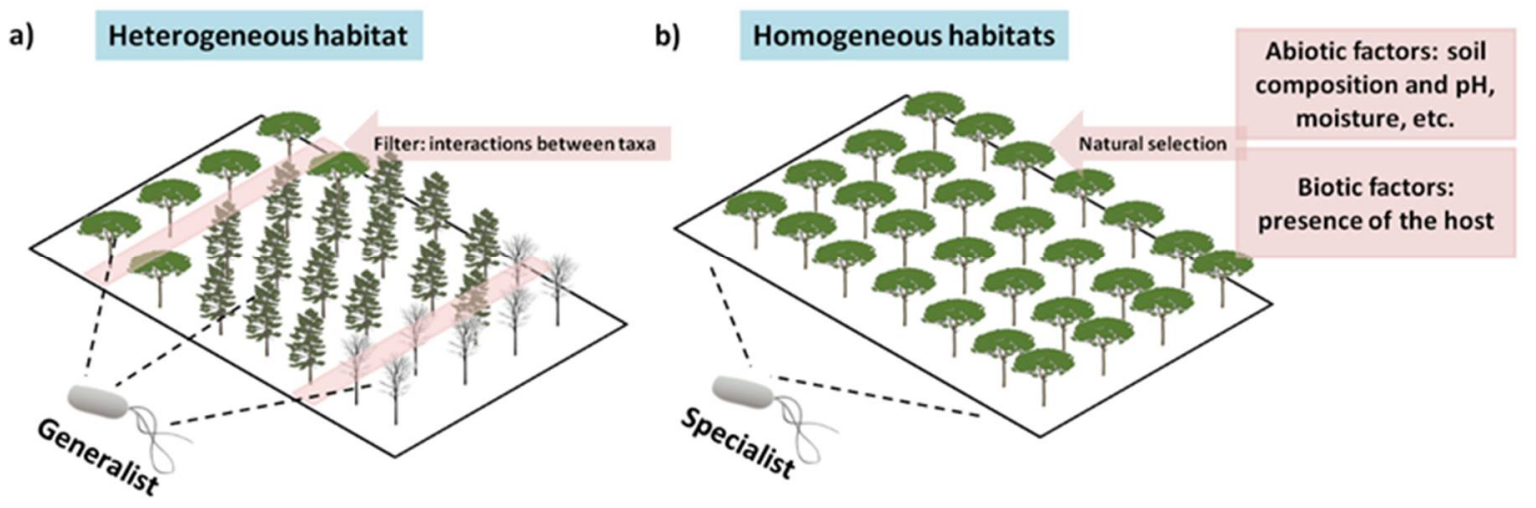

Figure 4. Development of habitat specialization in microbial species. More heterogeneous or disturbed environments tend to be occupied by generalist species (a), whereas specialist species tend to develop in more homogeneous or constant environments and are determined by natural selection (b).

While we are unable to sample all habitats, surprises continue to occur in the microbiological universe that stimulate research, especially on extremophiles. Studies show that microorganisms have successfully colonized the cold environments of the Earth, from the Arctic to the Antarctic and from high-mountain environments to the deep ocean, including permafrost soils, marine sediments, and sea and glacial ice [172-175]. Indeed, the polar and alpine regions, as well as the rest of the planet, share high genetic and functional diversity of prokaryotes (archaea and bacteria), eukaryotes (microalgae and microfungi), and viruses [176-181]. Polar and alpine habitats, once considered inhospitable, are now a vast source of undescribed microbial diversity. Accordingly, efforts have already been stepped up to assess the diversity of hydrothermal systems distributed throughout the planet, including sources found in geothermal fields located along the Main Mantle Thrust and the Main Karakoram Thrust in the Himalayas or in the Tattapani hot forest in the northwestern Himalayas; thermal springs of the Tibetan Plateau, Nakabusa (Japan), and Thailand; sources of hot and acidic water in the Colombian Andes; and not only thermal but also alkaline springs in Tengchong, Yunnan Province, southwest China, and Yellowstone National Park [182-189]. These sites, similar to lakes with salinity levels close to or above saturation, cold abyssal regions, or areas bombarded with high radiation levels, have also been described as habitats for some microbial species.

The Great Salt Lake in Utah (USA), for example, is a hypersaline lake where $\mathrm{NaCl}$ accounts for $86 \%$ of the total salt and is one of the most extreme environments in the world, even for microorganisms. However, in a recent metagenomics study, Tazi et al. [190] assessed the microbial diversity of water samples from this lake and found that they contained high sulfur levels, in addition to high salt concentration, and that they were derived from unique environmental gradients, such as oil infiltrations. Nevertheless, 58 operational taxonomic units of archaea and 42 of bacteria were identified. Phylogenetic analysis, therefore, demonstrated the high diversity of microbial communities in this lake. High abundance and diversity has also been described for the microbial community present in the salt lake Chott El Djerid in Tunisia [191] and in alkaline-saline soils in the regions of the Caspian Depression, where 40 species of bacteria were identified, with the genera Bacillus and Salimicrobium being the primary components of these communities [192]. 
The survival of microbial communities in deep, cold, and oligotrophic seawater has been frequently reported. Zhang et al. [193] isolated bacteria from the South Pacific Gyre and evaluated the potential of these bacteria to produce psychrophilic enzymes. Actinobacteria of the genera Dermacoccus, Kocuria, Micromonospora, Streptomyces, Tsukamurella, and Williamsia were isolated at a depth of 10,898 meters in the Mariana Trench [194]. Bacteria that thrive in deep oceans cope with high pressures and low temperatures. Despite these extreme conditions, the deep sea is estimated to be the last great unexplored frontier on Earth, harboring the largest microbial diversity on the planet, yet unknown and unexplored [195]. The uniform abyssal environment would be the cause of the great diversity and of the low abundance of microorganisms; in this environment, chemoautotrophs dominate, feeding on sources of reduced organic compounds [196].

Solar radiation-resistant extremophiles have recently been prospected from environments with high rates of ionizing radiation. Radiation resistance is regarded as an incidental adaptation of the resistance to desiccation, because both hazards cause similar cellular damage. Thus, desert soils are promising targets for prospecting for new radiation-resistant strains. Musilova et al. [197] isolated radiation-resistant Halomonas strains from the extreme cold desert of the Antarctic Dry Valleys using gamma-ray exposure preselection. An Acinetobacter sp. was isolated from high-altitude Andean lakes in the Argentinean Puna, an ecosystem with one of Earth's highest levels of UV exposure. This isolate showed an ability to efficiently repair DNA photodamage, coupled with highly efficient antioxidant enzyme activity in response to UV-B stress [198]. Methanosarcina soligelidi, isolated from Siberian permafrost, showed a level of resistance to radiation that was comparable to that of Deinococcus radiodurans [199]. A great diversity of bacteria of the genus Deinococcus, which are resistant to radiation doses of $15 \mathrm{kGy}$, were isolated from high-altitude soils in Tibet [200]. Deinococcus radiodurans is an icon of radiation resistance. Its tolerance is explained by highly efficient proteome protection, as a well-protected, functional proteome ensures cellular recovery from damage caused by extensive radiation to other cellular constituents via molecular repair and turnover processes, including efficient repair of disintegrated DNA [201].

Microorganisms in hostile environments may also require resistance mechanisms for more than one stress simultaneously, such as high-salinity environments exposed to high radiation. The problem for these microorganisms is to become known before becoming extinct, considering that anthropogenic effects on the environment affect specialists more strongly than generalists, since the former have resource constraints triggered by habitat preference.

\section{Why Should We Know About Microbial Diversity?}

The knowledge of microbial diversity, involving the discovery of new species and new molecules, has profoundly impacted several sectors, including the food industry; agriculture; environment; and the production of chemicals, fuels, and biomaterials. This contemporary and applied microbiology is known as Technological Microbiology and has employed complex techniques, such as heterologous expression and metabolic engineering, to generate new products and improve products and services [202].

The prospection of lactic acid bacteria present in fermented products has allowed us to obtain probiotics, a class of foods currently in high demand due to their benefits to consumer health [203-205]. In these foods, the activity of bacteria, especially of the genera Lactobacillus and Bifidobacterium but also of Enterococcus and Pediococcus [206-208], results in functional foods, including non-dairy probiotic beverages [209]. In addition, pre-cooked dough and clarified beverages are available on the market thanks to microbial enzymes, such as amylases, pectinases, and cellulases [210-213].

The edible mushroom market has become increasingly widespread worldwide. The number of mushrooms used in world cuisine is estimated to range from 200 to 3000 species, of which only 200 are commercially grown and 10 to 20 are currently grown on an industrial scale [214]. Agaricus bisporus, Lentinula edodes, Pleurotus ostreatus, and Flammulina velutipes are some of the primary species that are consumed. Mushrooms are sought after as a great alternative source of protein, although 
many mushrooms are prized for producing secondary metabolites with medicinal effects [215,216]. Protein extracted from cultured microbial biomass (single-cell protein-SCP) is also being used for protein supplementation of staple diets by replacing conventional protein sources [217]. The global animal protein market is several hundred million tons per year, and that of plant protein is several billion tons of protein per year; thus, expanding the production of microbial protein will not be challenging [218]. Bacterial strains of the genera Bacillus, Hydrogenomonas, Methanomonas, Methylomonas, and Pseudomonas have been used as substrates for industrial-scale SCP production, since such bacterial strains reach approximately $80 \%$ crude protein on a total dry weight basis. Yeasts, such as Saccharomyces, Candida, and Rhodotorula; filamentous fungi, including Fusarium, Aspergillus, and Penicillium; and even prokaryotic algae, such as those of the genus Spirulina, with approximately $65 \%$ of their dry weight consisting of protein [219], are currently used to produce SCPs.

Microorganisms have been historically used as excellent sources of antibiotics and bioactive molecules. Recently, Ling et al. [157] developed an important method that enabled the in situ growth of soil microorganisms that were unculturable under laboratory conditions. This method allowed for testing of chemicals that are naturally produced by microorganisms, including teixobactin, the first compound of an important new class of antibiotics. Teixobactin was shown to be able to eliminate methicillin-resistant Staphylococcus aureus, and bacteria are unlikely to develop resistance to teixobactin, because this molecule targets the wall precursor's lipids, which are essential to the maintenance of the bacterial cell wall [220]. Thus, access to microorganisms that have not yet been isolated will allow prospecting for new molecules with antimicrobial potential. Perhaps this is the weapon that will win the fight against microbial strains that are resistant to the wide diversity of antibiotics currently available on the market.

Currently, the application of microbial enzymes is focused on several markets, including cellulose and paper, leather, detergents and textiles, pharmaceuticals, chemicals, food and beverages, biofuels, animal feed, and personal care, among others [221]. The use of these enzymes in the food industry has contributed to the diversification and efficiency of food production by reducing the energy consumed in the production process [222]. Important microbial enzymes, such as $\alpha$-amylase, $\beta$-galactosidase, cellulase, hemicellulase, pectinase, protease, and tannase, among others [223,224], are currently produced in bioreactors by solid-state fermentation (SSF), and thermophilic bacteria and fungi show high potential for enzymatic synthesis in SSF processes. In turn, approaches using recombinant DNA are promising, because they will allow the overexpression of these enzymes and other microbial metabolites. Microbial enzymes have also been widely applied to wastewater treatment (e.g., [225,226]) and in the development of industrial bioprocesses. Today, new, improved, or more versatile enzymes are needed to develop more innovative, sustainable, and economically competitive production processes [221]. Knowledge of microbial diversity and of modern molecular techniques, such as metagenomics and genomics, will help in the discovery of new microbial enzymes with catalytic properties that can be improved/modified using different strategies. The use of enzymes in waste treatment, for example, has been affected by the scant knowledge on enzyme-producing species that are potentially applicable to the process, as only approximately $2 \%$ of the world's microorganisms have been tested as sources of enzymes [227].

In the field of agriculture, research is focused on identifying the microbial diversity associated with plant roots or with other plant tissues. Microorganisms that synthesize compounds, primarily those with herbicidal, insecticidal, and nematicidal activity, are also studied. Some microorganisms act as phytopathogen controllers. This is the case for species of the genus Trichoderma, which parasitize and successfully control Sclerotinia [228,229], Fusarium [230], Verticillium [231], and Macrophomina [232] fungal species, among others, and show nematicidal activity against gall-forming Meloidogyne species [233-235]. In addition, the evaluation of functional traits of mycorrhizal, rhizospheric, or endophytic species has identified species with high potential to promote plant growth. This growth promotion may result from biological nitrogen fixation, primarily by rhizobacteria (e.g., [236,237]), phytohormone synthesis [238], and biocontrol of phytopathogens, through the synthesis of antibiotics 
or siderophores, competition for nutrients, and induction of systemic resistance [239,240]. Although many efforts have been made in recent years to understand the diversity of microbial communities associated with a range of plant species, much work still needs to be done to assess the effect of abiotic or evolutionary factors on the structure of these communities.

Recently, new materials, developed from the discovery of bacterial metabolic properties, have been introduced in the technology market. For example, microbial bioplastics are currently used to manufacture medical materials, including films used as drug-delivery vehicles [241] or materials used in civil construction, making construction less expensive and more efficient [242]. The prospect of discovering new microorganisms or new properties in already known microorganisms, and the possibility of modifying them through genetic engineering, or even the possibility of stimulating naturally expressed pathways to elicit the synthesis of metabolites of interest, illustrates the importance of microbial biodiversity in strengthening Technological Microbiology [202], which has greatly affected the daily lives of people by providing new products and services.

\section{Additional Observations}

Despite all current knowledge on microbial diversity, we believe that additional evidence may result from long-term studies conducted in unexplored sites, especially those located in high-diversity areas, such as the tropics and marine ecosystems. Molecular studies have revealed a vast and unknown speciation, primarily in the Bacteria and Archaea domains, which comprise the underexplored microbiota. Efforts such as the large-scale sequencing of environmental samples may contribute to a clearer picture of the number of microbial species the planet harbors, but how long will it take to unravel the microbial diversity of the planet? According to Blackwell [243], the molecular tools in use and under development will allow for the discovery of the world's unknown fungi in less than 1000 years; for bacteria and archaea, estimates must be far higher, revealing the mountain of work still ahead of us. The challenge now is to train microbiologists and to adapt research laboratories to operate molecular techniques, although perhaps the greatest difficulty is the access to these techniques. The known microbial diversity can be thought of metaphorically as a small box within a large box that is able to house a much larger number of microorganisms, i.e., the estimated microbial diversity (Figure 5). However, several factors affect the small box, preventing the disclosure of the contents of the large box, and as predicted by Amann [72], many microbiologists continue to wonder anxiously "Who else is out there?"

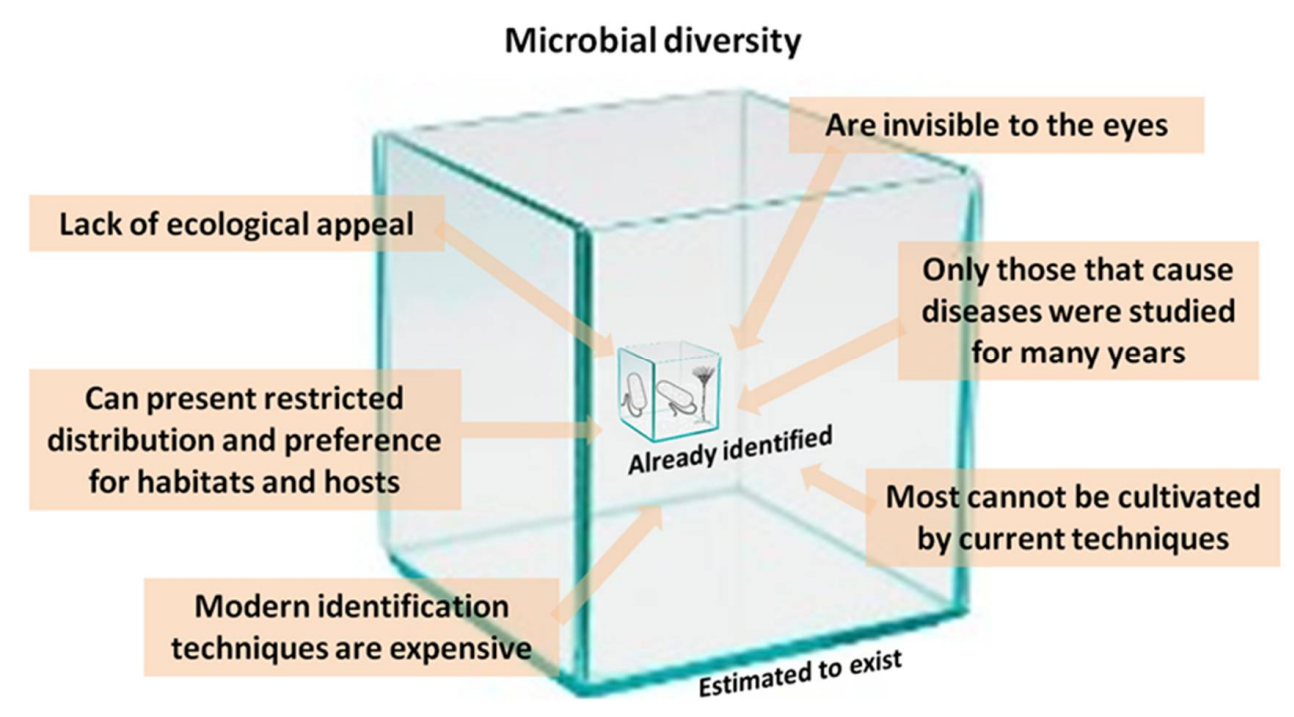

Figure 5. Comparative representation of the known and estimated (small box) and the yet unknown (large box) microbial diversity. The text boxes refer to factors that adversely affect the knowledge of the microbial diversity that exists on the planet. 
Author Contributions: Conceptualization, L.C.V.; Writing-Original Draft Preparation, L.C.V.; Writing-Review \& Editing, L.A.B.; Visualization, L.A.B.; Supervision, L.A.B.

Funding: This research received no external funding.

Acknowledgments: We thank the Goiano Federal Institute for the institutional support in the execution of the research.

Conflicts of Interest: The authors declare no conflict of interest.

\section{References}

1. Magurran, A.E. Measuring Biological Diversity; Blackwell: Oxford, UK, 2004; 264p.

2. Jonsson, P.R.; Hinrichsen, H.H.; Kotta, J.; Kotterba, P.; Middelboe, A.L.; Oesterwind, D.; Bonsdorff, E. Report on the importance of connectivity as a driver of biodiversity (populations, species, communities, habitats). Bonus Bio-C3 2016, 3, 1-27. [CrossRef]

3. Pomeroy, L.R. The ocean's food web, a changing paradigm. BioScience 1974, 24, 499-504. [CrossRef]

4. Azam, F.; Fenchel, T.; Field, J.G.; Gray, J.S.; Meyer-Reil, L.A.; Thingstad, F. The ecological role of water-column microbes in the sea. Mar. Ecol. Prog. Ser. 1983, 10, 257-263. [CrossRef]

5. Agenda, S. Systematics Agenda 2000: Charting the Biosphere; Technical Report; Systematics Agenda: New York, NY, USA, 1994; pp. 1-34.

6. Claridge, M.F. Introducing systematic Agenda 2000. Biodivers. Conserv. 1995, 4, 451-452. [CrossRef]

7. Joppa, L.N.; Roberts, D.L.; Myers, N.; Pimm, S.L. Biodiversity hotspots house most undiscovered plant species. Proc. Natl. Acad. Sci. USA 2011, 108, 13171-13176. [CrossRef] [PubMed]

8. Mora, C.; Tittensor, D.P.; Adl, S.; Simpson, A.G.B.; Worm, B. How many species are there on earth and in the ocean? PLoS Biol. 2011, 9, e1001127. [CrossRef] [PubMed]

9. Daly, M.; Herendeen, P.S.; Guralnick, R.P.; Westneat, M.W.; McDade, L. Systematics Agenda 2020: The Mission Evolves. Syst. Biol. 2012, 61, 549-552. [CrossRef] [PubMed]

10. May, R.M.; Beverton, R.J.H. How many species? Philos. Trans. R. Soc. Lond. B Biol. Sci. 1990, 330, $293-304$. [CrossRef]

11. May, R.M. How many species are there on earth? Science 1988, 241, 1441-1449. [CrossRef] [PubMed]

12. Erwin, T.L. Beetles and other insects of tropical forest canopies at Manaus, Brazil, sampled by insecticidal fogging. In Tropical Rainforest: Ecology and Management; Sutton, S.L., Whitmore, T.C., Chadwick, A.C., Eds.; Blackwell Scientific Publications: Oxford, UK, 1983; pp. 59-75.

13. Raven, P.H. Disappearing species: A global tragedy. Futurist 1985, 19, 8-14.

14. Stork, N.E. How many species are there? Biodivers. Conserv. 1993, 2, 215-232. [CrossRef]

15. Reid, W.V.; Miller, K.R. Keeping Options Alive: The Scientific Basis for Conserving Biological Diversity; World Resources Institute: Washington, DC, USA, 1989; 129p.

16. Reid, W.V. How many species will there be? In Tropical Deforestation and Species Extinction; Whitmore, T.C., Sayer, J.A., Eds.; Chapmam \& Hall: London, UK; New York, NY, USA; Tokyo, Japan; Melbourne, Australia; Madras, India, 1992; pp. 55-73.

17. Simberloff, D. Are we on the verge of a mass extinction in tropical rain forests? In Dynamics of Extinction; Elliott, D.K., Ed.; Wiley: New York, NY, USA, 1986; pp. 165-180.

18. Dirzo, R.; Raven, P.H. Global state of biodiversity and loss. Annu. Rev. Environ. Resour. 2003, 28, $137-167$. [CrossRef]

19. Gibson, L.; Lee, T.M.; Koh, L.P.; Gardner, T.A.; Barlow, J.; Peres, C.A. Primary forests are irreplaceable for sustaining tropical biodiversity. Nature 2011, 478, 378-381. [CrossRef] [PubMed]

20. Chazdon, R.L. Beyond deforestation: Restoring forests and ecosystem services on degraded lands. Science 2008, 320, 1458-1460. [CrossRef] [PubMed]

21. Pereira, H.M. A latitudinal gradient for genetic diversity. Science 2016, 353, 1494-1495. [CrossRef] [PubMed]

22. Gentry, A.H. Tropical forest biodiversity: Distributional patterns and their conservational significance. Oikos 1992, 63, 19-28. [CrossRef]

23. Myers, N.; Mittermeier, R.A.; Mittermeier, C.G.; da Fonseca, G.A.; Kent, J. Biodiversity hotspots for conservation priorities. Nature 2000, 403, 853-858. [CrossRef] [PubMed]

24. Groombridge, B.; Jenkins, M.D. Global Biodiversity: Earth's Living Resources in the 21st Century; World Conservation Press: Cambridge, UK, 2000; 364p. 
25. Reaka-Kudla, M.L. The global biodiversity of coral reefs: A comparison with rain forests. In Biodiversity II; Reaka-Kudla, M.L., Wilson, D.E., Wilson, E.O., Eds.; Joseph Henry Press: Washington, DC, USA, 1997; pp. 83-108.

26. Minelli, A. Biological Systematic; Chapman and Hall: London, UK, 1993; 299p.

27. Hammond, P.M. The current magnitude of biodiversity. In Global Biodiversity Assessment; Heywood, V.H., Watson, R.T., Eds.; Cambridge University Press: Cambridge, UK, 1995; pp. 113-138.

28. Brusca, R.C.; Brusca, G.J. Invertebrates; Sinauer Associates: Sunderland, MA, USA, 2003; 936p.

29. Bouchet, P. The magnitude of marine biodiversity. In The Exploration of Marine Biodiversity; Duarte, C.M., Ed.; Fundación BBVA: Bilbao, Spain, 2006; pp. 31-62.

30. Locey, K.J.; Lennon, J.T. Scaling laws predict global microbial diversity. Proc. Natl. Acad. Sci. USA 2016, 113, 5970-5975. [CrossRef] [PubMed]

31. Torsvik, V.; Øvreås, L.; Thingstad, T.F. Prokaryotic diversity-magnitude, dynamics, and controlling factors. Science 2002, 296, 1064-1066. [CrossRef] [PubMed]

32. Gans, J.; Wolinsky, M.; Dunbar, J. Computational improvements reveal great bacterial diversity and high metal toxicity in soil. Science 2005, 309, 1387-1390. [CrossRef] [PubMed]

33. Roesch, L.F.W.; Fulthorpe, R.R.; Riva, A.; Casella, G.; Hadwin, A.K.; Kent, A.D.; Daroub, S.H.; Camargo, F.A.; Farmerie, W.G.; Triplett, E.W. Pyrosequencing enumerates and contrasts soil microbial diversity. ISME J. 2007, 1, 283-290. [CrossRef] [PubMed]

34. Curtis, T.P.; Sloan, W.T.; Scannell, J.W. Estimating prokaryotic diversity and its limits. Proc. Natl. Acad. Sci. USA 2002, 99, 10494-10499. [CrossRef] [PubMed]

35. Chun, J.; Rainey, F.A. Integrating genomics into the taxonomy and systematics of the Bacteria and Archaea. Int. J. Syst. Evol. Microbiol. 2014, 64, 316-324. [CrossRef] [PubMed]

36. Wilson, E.O. The Diversity of Life; Harvard University Press: New York, NY, USA, 1994; 440p.

37. Pace, N.R. A molecular view of microbial diversity and the biosphere. Science 1997, 276, 734-740. [CrossRef] [PubMed]

38. Ghiorse, W.C. Subterranean life. Science 1997, 275, 789-790. [CrossRef]

39. Martin, W.F.; Sousa, F.L. Early microbial evolution: The age of anaerobes. Cold Spring Harb. Perspect. Biol. 2015, 8, 2a018127. [CrossRef] [PubMed]

40. DeLong, E.F.; Pace, N.R. Environmental diversity of bacteria and archaea. Syst. Biol. 2001, 50, 471-478. [CrossRef]

41. Zahn, L.M. Archaeal diversity and evolution. Science 2017, 357, 560-562. [CrossRef]

42. Hug, L.A.; Baker, B.J.; Anantharaman, K.; Brown, C.T.; Probst, A.J.; Castelle, C.J.; Butterfield, C.N.; Hernsdorf, A.W.; Amano, Y.; Ise, K.; et al. A new view of the tree of life. Nat. Microbiol. 2016, 16048. [CrossRef] [PubMed]

43. Dykhuizen, D.E. Santa Rosalia revisited: Why are there so many species of bacteria? Antonie Leeuwenhoek 1998, 73, 25-33. [CrossRef] [PubMed]

44. Hawksworth, D.L. The fungal dimension of biodiversity: Magnitude, significance, and conservation. Mycol. Res. 1991, 95, 641-655. [CrossRef]

45. Hawksworth, D.L. The magnitude of fungal diversity: The 1.5 million species estimate revisited. Mycol. Res. 2001, 105, 1422-1432. [CrossRef]

46. O’Brien, B.L.; Parrent, J.L.; Jackson, J.A.; Moncalvo, J.M.; Vilgalys, R. Fungal community analysis by large-scale sequencing of enviromental samples. Appl. Environ. Microbiol. 2005, 71, 5544-5550. [CrossRef] [PubMed]

47. Hawksworth, D.L. Global species numbers of fungi: Are tropical studies and molecular approaches contributing to a more robust estimate? Biodivers. Conserv. 2012, 21, 2425-2433. [CrossRef]

48. Tedersoo, L.; Nara, K. General latitudinal gradient of biodiversity is reversed in ectomycorrhizal fungi. New Phytol. 2010, 185, 351-354. [CrossRef] [PubMed]

49. Hawksworth, D.L.; Rossman, A.Y. Where are all the undescribed fungi? Phytopathology 1997, 87, 888-891. [CrossRef] [PubMed]

50. Gilbert, G.S.; Ferrer, A.; Carranza, J. Polypore fungal diversity and host density in a moist tropical forest. Biodivers. Conserv. 2002, 11, 947-957. [CrossRef]

51. Brundrett, M.C.; Ashwath, N. Glomeromycotan mycorrhizal fungi from tropical Australia III. Measuring diversity in natural and disturbed habitats. Plant Soil 2013, 370, 419-433. [CrossRef] 
52. Schimann, H.; Bach, C.; Lengelle, J.; Louisanna, E.; Barantal, S.; Murat, C.; Buée, M. Diversity and structure of fungal communities in neotropical rainforest soils: The effect of host recurrence. Microb. Ecol. 2017, 73, 310-320. [CrossRef] [PubMed]

53. Letcher, P.M.; Powell, M.J. Kappamyces a new genus in the Chytridiales (Chytridiomycota). Nova Hedwig. 2005, 80, 115-133. [CrossRef]

54. Kirk, P.M.; Cannon, P.F.; Minter, D.W.; Stalpers, J.A. Dictionary of the Fungi; CABI: Wallingford, UK, 2008; 784p.

55. Hibbett, D.S.; Binder, M.; Bischoff, J.F.; Blackwell, M.; Cannon, P.F.; Eriksson, O.E.; Huhndorf, S.; James, T.; Kirk, P.M.; Lücking, R. A higher-level phylogenetic classification of the Fungi. Mycol. Res. 2007, 111, 509-547. [CrossRef] [PubMed]

56. van der Wal, A.; Geydan, T.D.; Kuyper, T.W.; Boer, W. A thready affair: Linking fungal diversity and community dynamics to terrestrial decomposition processes. FEMS Microbiol. Rev. 2013, 37, 477-494. [CrossRef] [PubMed]

57. Schüßler, A.; Schwarzott, D.; Walker, C. A new fungal phylum, the Glomeromycota: Phylogeny and evolution. Mycol. Res. 2001, 105, 1413-1421. [CrossRef]

58. van der Heijden, M.G.A.; Martin, F.M.; Selosse, M.-A.; Sanders, I.R. Mycorrhizal ecology and evolution: The past, the present, and the future. New Phytol. 2015, 205, 1406-1423. [CrossRef] [PubMed]

59. Öpik, M.; Zobel, M.; Cantero, J.J.; Davison, J.; Facelli, J.M.; Hiiesalu, I.; Jairus, T.; Kalwij, J.M.; Koorem, K.; Leal, M.E. Global sampling of plant roots expands the described molecular diversity of arbuscular mycorrhizal fungi. Mycorrhiza 2013, 23, 411-430. [CrossRef] [PubMed]

60. Kivlin, S.N.; Hawkes, C.V.; Treseder, K.K. Global diversity and distribution of arbuscular mycorrhizal fungi. Soil Biol. Biochem. 2011, 43, 2294-2303. [CrossRef]

61. Comandini, O.; Rinaldi, A.C.; Kuyper, T.W. Measuring and estimating ectomycorrhizal fungal diversity: Acontinuous challenge. In Mycorrhiza: Occurrence in Natural and Restored Environments; Pagano, M., Ed.; Nova Science Publishers: New York, NY, USA, 2012; pp. 165-200.

62. Tedersoo, L.; May, T.W.; Smith, M.E. Ectomycorrhizal lifestyle in fungi: Global diversity, distribution, and evolution of phylogenetic lineages. Mycorrhiza 2010, 20, 217-263. [CrossRef] [PubMed]

63. Walker, J.F.; Aldrich-Wolfe, L.; Riffel, A.; Barbare, H.; Simpson, N.B.; Trowbridge, J.; Jumpponen, A. Diverse Helotiales associated with the roots of three species of Arctic Ericaceae provide no evidence for host specificity. New Phytol. 2011, 191, 515-527. [CrossRef] [PubMed]

64. Arnold, A.E.; Maynard, Z.; Gilbert, G.S.; Coley, P.D.; Kursar, T.A. Are tropical fungal endophytes hyperdiverse? Ecol. Lett. 2000, 3, 267-274. [CrossRef]

65. Arnold, A.E.; Lutzoni, F. Diversity and host range of foliar fungal endophytes: Are tropical leaves biodiversity hotspots? Ecology 2007, 88, 541-549. [CrossRef] [PubMed]

66. Clay, K.; Shearin, Z.R.C.; Bourke, K.A.; Bickford, W.A.; Kowalski, K.P. Diversity of fungal endophytes in non-native Phragmites australis in the Great Lakes. Biol. Invasions 2016, 18, 2703-2716. [CrossRef]

67. Shetty, K.G.; Rivadeneira, D.V.; Jayachandran, K. Isolation and molecular characterization of the fungal endophytic microbiome from conventionally and organically grown avocado trees in South Florida. Mycol. Prog. 2016, 15, 977-986. [CrossRef]

68. Robinson, R.J.; Fraaije, B.A.; Clark, I.M.; Jackson, R.W.; Hirsch, P.R. Endophytic bacterial community composition in wheat (Triticum aestivum) is determined by plant tissue type, developmental stage and soil nutrient availability. Plant Soil 2016, 405, 381-396. [CrossRef]

69. Blevins, S.M.; Bronze, M.S. Robert Koch and the 'golden age' of bacteriology. Int. J. Infect. Dis. 2010, 14, e744-e751. [CrossRef] [PubMed]

70. Plotkin, S.L.; Plotkin, S.A. A short history of vaccination. In Vaccines; Plotkin, S.A., Orenstein, W.A., Eds.; Elsevier: Philadelphia, PA, USA, 2004; pp. 1-16. [CrossRef]

71. Pasteur, L. Summary report of the experiments conducted at Pouilly-le-Fort, near Melun, on the anthrax vaccination, 1881. Yale J. Biol. Med. 2002, 75, 59-62. [PubMed]

72. Amann, R. Who is out there? Microbial aspects of biodiversity. Syst. Appl. Microbiol. 2000, 23, 1-8. [CrossRef]

73. White, R.T. The link between the laboratory and learning. Int. J. Sci. Educ. 1996, 18, 761-774. [CrossRef]

74. Gott, R.; Duggan, S. Practical work: Its role in the understanding of evidence in science. Int. J. Sci. Educ. 1996, 18, 791-806. [CrossRef]

75. Prokop, P.; Prokop, M.; Tunnicliffe, S.D. Is biology boring? Student attitudes toward biology. J. Biol. Educ. 2007, 42, 36-39. [CrossRef] 
76. Ackert, L. The 'Cycle of Life' in Ecology: Sergei Vinogradskii's Soil Microbiology, 1885-1940. J. Hist. Biol. 2007, 40, 109-145. [CrossRef]

77. Chung, K.T.; Ferris, D.H. Martinus Willem Beijerinck (1851-1931): Pioneer of general microbiology. ASM News 1996, 62, 539-543.

78. Donaldson, G.P.; Lee, S.M.; Mazmanian, S.K. Gut biogeography of the bacterial microbiota. Nat. Rev. Microbiol. 2016, 14, 20-32. [CrossRef] [PubMed]

79. van Rensburg, J.J.; Dbeibo, L.; Spinola, S.M. The cutaneous microbiota as a determinant of skin barrier function: Molecular interactions and therapeutic opportunities. In Skin Stress Response Pathways; Wondrak, G., Ed.; Springer: Cham, Switzerland, 2016; pp. 379-401. [CrossRef]

80. Fredricks, D. The Vaginal Microbiome. In Molecular Microbiology; ASM Press: Washington, DC, USA, 2016; pp. 138-145.

81. Turnbaugh, P.J.; Ley, R.E.; Hamady, M.; Fraser-Liggett, C.; Knight, R.; Gordon, J.I. The human microbiome project: Exploring the microbial part of ourselves in a changing world. Nature 2007, 449, 804-810. [CrossRef] [PubMed]

82. Zárate-Bladés, C.R.; Horai, R.; Caspi, R.R. Regulation of Autoimmunity by the Microbiome. DNA Cell Biol. 2016, 35, 455-458. [CrossRef] [PubMed]

83. Thaiss, C.A.; Zmora, N.; Levy, M.; Elinav, E. The microbiome and innate immunity. Nature 2016, 535, 65-74. [CrossRef] [PubMed]

84. Calo-Mata, P.; Ageitos, J.M.; Böhme, K.; Barros-Velázquez, J. Intestinal microbiota: First barrier against gut-affecting pathogens. In New Weapons to Control Bacterial Growth; Villa, T., Vinas, M., Eds.; Springer: Cham, Switzerland, 2016; pp. 281-314. [CrossRef]

85. Khoroshkin, M.S.; Rodionov, D. Syntrophic metabolism of vitamins and amino acids in gut microbial community as revealed by in silico genomic analyses. FASEB J. 2016, 30, 819.5.

86. LeBlanc, J.G.; Chain, F.; Martín, R.; Bermúdez-Humarán, L.G.; Courau, S.; Langella, P. Beneficial effects on host energy metabolism of short-chain fatty acids and vitamins produced by commensal and probiotic bacteria. Microb. Cell Fact. 2017, 16, 79. [CrossRef] [PubMed]

87. Kamaroff, A.L. The microbiome and risk for obesity and diabetes. JAMA 2017, 317, 355-356. [CrossRef] [PubMed]

88. Michereff, S.J.; Domingos, E.G.T.; Andrade, M.M. Ecologia e Manejo de Patógenos Radiculares em Solos Tropicais; UFRPE, Imprensa Universitária: Recife, Brazil, 2005; 388p.

89. Jordan, D.C. Transfer of Rhizobium japonicum Buchanan 1980 to Bradyrhizobium gen. nov., a genus of slow-growing, root nodule bacteria from leguminous plants. Int. J. Syst. Bacteriol. 1982, 32, 136-139. [CrossRef]

90. He, Z.; Wang, J.; Hu, J.; Zhang, H.; Cai, C.; Shen, J.; Xu, X.; Zheng, P.; Hu, B. Improved PCR primers to amplify 16S rRNA genes from NC10 bacteria. Appl. Microbiol. Biotechnol. 2016, 100, 5099-5108. [CrossRef] [PubMed]

91. Baker, G.C.; Smith, J.J.; Cowan, D.A. Review and re-analysis of domain-specific $16 \mathrm{~S}$ primers. J. Microbiol. Methods 2003, 55, 541-555. [CrossRef] [PubMed]

92. Nübel, U.; Garcia-Pichel, F.; Muyzer, G. PCR primers to amplify 16S rRNA genes from cyanobacteria. Appl. Environ. Microbiol. 1997, 63, 3327-3332. [PubMed]

93. Tedersoo, L.; Bahram, M.; Puusepp, R.; Nilsson, R.H.; James, T.Y. Novel soil-inhabiting clades fill gaps in the fungal tree of life. Microbiome 2017, 5, 42. [CrossRef] [PubMed]

94. Xu, W.; Luo, Z.-H.; Guo, S.; Pang, K.-L. Fungal community analysis in the deep-sea sediments of the Pacific Ocean assessed by comparison of ITS, $18 \mathrm{~S}$ and $28 \mathrm{~S}$ ribosomal DNA regions. Deep Sea Res. Part I Oceanogr. Res. Pap. 2016, 109, 51-60. [CrossRef]

95. Janda, J.M.; Abbott, S.L. 16S rRNA gene sequencing for bacterial identification in the diagnostic laboratory: Pluses, perils, and pitfalls. Clin. Microbiol. 2007, 45, 2761-2764. [CrossRef] [PubMed]

96. Subrahmanyam, C.S.; Cassidy, B.; Busch, H.; Rothblum, L.I. Nucleotide sequence of the region between the $18 \mathrm{~S}$ rRNA sequence and the $28 \mathrm{~S}$ rRNA sequence of rat ribosomal DNA. Nucleic Acids Res. 1982, 10, 3667-3680. [CrossRef] [PubMed]

97. Rubtsov, P.M.; Musakhanov, M.M.; Zakharyev, V.M.; Krayev, A.S.; Skryabin, K.G.; Bayev, A.A. The structure of the yeast ribosomal RNA genes. I. The complete nucleotide sequence of the $18 \mathrm{~S}$ ribosomal RNA gene from Saccharomyces cerevisiae. Nucleic Acids Res. 1980, 8, 5779-5794. [CrossRef] [PubMed] 
98. Leal, P.L.; Stürmer, S.L.; Siqueira, J.O. Occurrence and diversity of arbuscular mycorrhizal fungi in trap cultures from soils under different land use systems in the Amazon, Brazil. Braz. J. Microbiol. 2009, 40, 111-121. [CrossRef] [PubMed]

99. de Oliveira Freitas, R.; Buscardo, E.; Nagy, L.; Maciel, A.B.S.; Carrenho, R.; Luizão, R.C.C. Arbuscular mycorrhizal fungal communities along a pedo-hydrological gradient in a Central Amazonian terra firme forest. Mycorrhiza 2014, 24, 21-32. [CrossRef] [PubMed]

100. Sarkar, U.; Choudhary, B.K.; Sharma, B.K. Vascular arbuscular mycorrhizal (VAM) spore diversity and density across the soil of degraded forest and rubber plantation in Tripura, India. Am.-Eurasian J. Agric. Environ. Sci. 2014, 14, 1080-1088. [CrossRef]

101. Husband, R.; Herre, E.A.; Turner, S.L.; Gallery, R.; Young, J.P.W. Molecular diversity of arbuscular mycorrhizal fungi and patterns of host association over time and space in a tropical forest. Mol. Ecol. 2002, 11, 2669-2678. [CrossRef] [PubMed]

102. Francisco, J.C.; Cohan, F.M.; Krizanc, D. Accuracy and efficiency of algorithms for the demarcation of bacterial ecotypes from DNA sequence data. Int. J. Bioinform. Res. Appl. 2014, 10, 409-425. [CrossRef] [PubMed]

103. Brochier-Armanet, C.; Forterre, P.; Gribaldo, S. Phylogeny and evolution of the Archaea: One hundred genomes later. Curr. Opin. Microbiol. 2011, 14, 274-281. [CrossRef] [PubMed]

104. Hugenholtz, P.; Goebel, B.M.; Pace, N.R. Impact of culture-independent studies on the emerging phylogenetic view of bacterial diversity. J. Bacteriol. 1998, 180, 4765-4774. [PubMed]

105. Bogaert, D.; Keijser, B.; Huse, S.; Rossen, J.; Veenhoven, R.; van Gils, E.; Bruin, J.; Montijn, R.; Bonten, M.; Sanders, E. Variability and diversity of nasopharyngeal microbiota in children: A metagenomic analysis. PLoS ONE 2011, 6, e17035. [CrossRef] [PubMed]

106. Zhernakova, A.; Kurilshikov, A.; Bonder, M.J.; Tigchelaar, E.F.; Schirmer, M.; Vatanen, T.; Mujagic, Z.; Vila, A.V.; Falony, G.; Vieira-Silva, S.; et al. Population-based metagenomics analysis reveals markers for gut microbiome composition and diversity. Science 2016, 352, 565-569. [CrossRef] [PubMed]

107. Wallace, R.J.; Rooke, J.A.; McKain, N.; Duthie, C.-A.; Hyslop, J.J.; Ross, D.W.; Waterhouse, A.; Watson, M.; Roehe, R. The rumen microbial metagenome associated with high methane production in cattle. BMC Genom. 2015, 16, 839. [CrossRef] [PubMed]

108. Vavourakis, C.D.; Ghai, R.; Rodriguez-Valera, F.; Sorokin, D.Y.; Tringe, S.G.; Hugenholtz, P.; Muyzer, G. Metagenomic insights into the uncultured diversity and physiology of microbes in four hypersaline Soda Lake Brines. Front. Microbiol. 2016, 7, 211. [CrossRef] [PubMed]

109. Hong, X.; Chen, J.; Liu, L.; Wu, H.; Tan, H.; Xie, G.; Xu, Q.; Zou, H.; Yu, W.; Wang, L.; Qin, N. Metagenomic sequencing reveals the relationship between microbiota composition and quality of Chinese Rice Wine. Sci. Rep. 2016, 6, 26621. [CrossRef] [PubMed]

110. Fierer, N.; Breitbart, M.; Nulton, J.; Salamon, P.; Lozupone, C.; Jones, R.; Robeson, M.; Edwards, R.A.; Felts, B.; Rayhawk, S.; et al. Metagenomic and small-subunit rRNA analyses reveal the genetic diversity of bacteria, archaea, fungi, and viruses in soil. Appl. Environ. Microbiol. 2007, 73, 7059-7066. [CrossRef] [PubMed]

111. Ferrer, M.; Werner, J.; Chernikova, T.N.; Bargiela, R.; Fernández, L.; La Cono, V.; Waldmann, J.; Teeling, J.; Golyshina, O.V.; Glöckner, F.O.; et al. Unveiling microbial life in the new deep-sea hypersaline Lake Thetis. Part II: A metagenomic study. Environ. Microbiol. 2012, 14, 268-281. [CrossRef] [PubMed]

112. Debroas, D.; Humbert, J.-F.; Enault, F.; Bronner, G.; Faubladier, M.; Cornillor, E. Metagenomic approach studying the taxonomic and functional diversity of the bacterial community in a mesotrophic lake (Lac du Bourget-France). Environ. Microbiol. 2009, 11, 2412-2424. [CrossRef] [PubMed]

113. Nacke, H.; Goldmann, K.; Schöning, I.; Pfeiffer, B.; Kaiser, K.; Castillo-Villamizar, G.A. Fine spatial scale variation of soil microbial communities under European beech and Norway spruce. Front. Microbiol. 2016, 7, 2067. [CrossRef] [PubMed]

114. Mašínová, T.; Bahnmann, B.D.; Větrovský, T.; Tomšovský, M.; Merunková, K.; Baldrian, P. Drivers of yeast community composition in the litter and soil of a temperate forest. FEMS Microbiol. Ecol. 2017, 93, fiw223. [CrossRef] [PubMed]

115. Lin, Y.-T.; Whitman, W.B.; Coleman, D.C.; Jien, S.-H.; Chiu, C.-Y. Cedar and bamboo plantations alter structure and diversity of the soil bacterial community from a hardwood forest in subtropical mountain. Appl. Soil Ecol. 2017, 112, 28-33. [CrossRef] 
116. Sheldrake, M.; Rosenstock, N.P.; Revillini, D.; Olsson, P.A.; Mangan, S.; Sayer, E.J.; Wallander, H.; Turner, B.L.; Tanner, E.V.J. Arbuscular mycorrhizal fungal community composition is altered by long-term litter removal but not litter addition in a lowland tropical forest. New Phytol. 2017, 214, 455-467. [CrossRef] [PubMed]

117. Sanders, I.R.; Rodriguez, A. Aligning molecular studies of mycorrhizal fungal diversity with ecologically important levels of diversity in ecosystems. ISME J. 2016, 10, 2780-2786. [CrossRef] [PubMed]

118. Hedlund, B.P.; Staley, J.T. Microbial endemism and biogeography. In Microbial Diversity and Bioprospecting; Bull, A.T., Ed.; ASM Press: Washington, DC, USA, 2004; pp. 225-231.

119. Green, J.; Bohannan, B.J.M. Spatial scaling of microbial biodiversity. Microb. Ecol. 2006, 21, 501-507. [CrossRef] [PubMed]

120. Pasternak, J. Novas metodologias de identificação de micro-organismos: MALDI-TOF. Einstein 2012, 10, 118-119. [CrossRef] [PubMed]

121. Benagli, C.; Rossi, V.; Dolina, M.; Tonolla, M.; Petrini, O. Matrix-assisted laser desorption ionization-time of flight mass spectrometry for the identification of clinically relevant bacteria. PLOS ONE 2011, 6, e16424. [CrossRef] [PubMed]

122. Neville, S.A.; LeCordier, A.; Ziochos, H.; Chater, M.J.; Gosbell, I.B.; Maley, M.W.; van Hal, S.J. The utility of matrix assisted laser desorption/ionization time-of-flight mass spectrometry (MALDI-TOF MS) following introduction for routine laboratory bacterial identification. J. Clin. Microbiol. 2011, 49, 2980-2984. [CrossRef] [PubMed]

123. Hsieh, S.-Y.; Tseng, C.-L.; Lee, Y.-S.; Kuo, A.-J.; Sun, C.-F.; Lin, Y.-H.; Chen, J.-K. Highly efficient classification and identification of human pathogenic bacteria by MALDI-TOF MS. Mol. Cell Proteom. 2008, 7, 448-456. [CrossRef] [PubMed]

124. Opota, O.; Prod'hom, G.; Greub, G. Applications of MALDI-TOF mass spectrometry in clinical diagnostic microbiology. In Maldi-Tof and Tandem MS for Clinical Microbiology; Shah, H.N., Gharbia, S.E., Eds.; Wiley: New York, NY, USA, 2017; pp. 55-92. [CrossRef]

125. Siller-Ruiz, M.; Hernández-Egido, S.; Sánchez-Juanes, F.; González-Buitrago, J.M.; Muñoz-Bellido, J.L. Fast methods of fungal and bacterial identification. MALDI-TOF mass spectrometry, chromogenic media. Enferm. Infecc. Microbiol. Clin. 2017, 35, 303-313. [CrossRef] [PubMed]

126. Kostrzewa, M.; Nagy, E. How MALDI-TOF mass spectrometry can aid diagnosis of hard-to-identify pathogenic bacteria. Expert Rev. Mol. Diagn. 2016, 16, 509-511. [CrossRef] [PubMed]

127. Lasch, P.; Grunow, R.; Antonation, K.; Weller, S.A.; Jacob, D. Inactivation techniques for MALDI-TOF MS analysis of highly pathogenic bacteria-A critical review. Trends Anal. Chem. 2016, 85, 112-119. [CrossRef]

128. Lasch, P.; Jacob, D.; Grunow, R.; Schwecke, T.; Doellinger, J. Matrix-assisted laser desorption/ionization time-of-flight (MALDI-TOF) mass spectrometry (MS) for the identification of highly pathogenic bacteria. Trends Anal. Chem. 2016, 85, 103-111. [CrossRef]

129. Bader, O. Fungal species identification by MALDI-TOF mass spectrometry. Methods Mol. Biol. 2017, 1508, 323-337. [CrossRef] [PubMed]

130. Popović, N.T.; Kazazić, S.P.; Strunjak-Perović, I.; Čož-Rakovac, R. Differentiation of environmental aquatic bacterial isolates by MALDI-TOF MS. Environ. Res. 2017, 152, 7-16. [CrossRef] [PubMed]

131. Martínez-Molina, E.; Juanes, F.S.; Carro, L.; Flores-Félix, J.D.; Martínez-Hidalgo, P.; Castillo, E.C.; Buitrago, J.M.G.; Velázquez, E. Identification of rhizobial strains nodulating Pisum sativum in northern spain soils by MALDI-TOF MS (Matrix-assisted laser desorption ionization time-of-flight mass spectrometry) analysis. In Biological Nitrogen Fixation and Beneficial Plant-Microbe Interaction; González-Andrés, F., James, E., Eds.; Springer International Publishing: Cham, Switzerland, 2016; pp. 37-44. [CrossRef]

132. Urquiza, C.C.; Hernández, I.A.; Medina, J.A.C.; López, M.A.R.; Cruz, J.P.; Zarazúa, R.L.R. Identification by MALDI-TOF mass spectrometry of mercury-resistant bacteria associated with the rhizosphere of an apple orchard. Geomicrobiol. J. 2016, 34, 176-182. [CrossRef]

133. Avanzi, I.R.; Gracioso, L.H.; Baltazar, M.P.G.; Karolski, B.; Perpetuo, E.A.; Nascimento, C.A.O. Rapid bacteria identification from environmental mining samples using MALDI-TOF MS analysis. Environ. Sci. Pollut. Res. Int. 2017, 24, 3717-3726. [CrossRef] [PubMed]

134. Finlay, B.J.; Clarke, K.J. Ubiquitous dispersal of microbial species. Nature 1999, 400, 828. [CrossRef]

135. Shurin, J.B.; Cottenie, K.; Hillebrand, H. Autocorrelação espacial e limitação da dispersão em organismos de água doce. Oecologia 2009, 159, 151-159. [CrossRef] [PubMed] 
136. Fenchel, T.; Finlay, B.J. The ubiquity of small species: Patterns of local and global diversity. BioScience 2004, 54, 777-784. [CrossRef]

137. Papke, R.T.; Ramsing, N.B.; Bateson, M.M.; Ward, D.M. Geographical isolation in hot spring cyanobacteria. Environ. Microbiol. 2003, 5, 650-659. [CrossRef] [PubMed]

138. Papke, R.T.; Ward, D.M. The importance of physical isolation to microbial diversification. FEMS Microbiol. Ecol. 2004, 48, 293-303. [CrossRef] [PubMed]

139. de Wit, R.; Bouvier, T. 'Everything is everywhere, but, the environment selects'; what did Baas Becking and Beijerinck really say? Environ. Microbiol. 2006, 8, 755-758. [CrossRef] [PubMed]

140. Martiny, J.B.; Bohannan, B.J.; Brown, J.H.; Colwell, R.K.; Fuhrman, J.A.; Green, J.L.; Horner-Devine, M.C.; Kane, M.; Krumins, J.A.; Kuske, C.R.; et al. Microbial biogeography: Putting microorganisms on the map. Nat. Rev. Microbiol. 2006, 4, 102-112. [CrossRef] [PubMed]

141. Telford, R.J.; Vandvik, V.; Birks, H.J.B. Dispersal limitations matter for microbial morphospecies. Science 2006, 312, 1015. [CrossRef] [PubMed]

142. Hanson, C.; Fuhrman, J.; Horner-Devine, M.C.; Martiny, J.B.H. Beyond biogeographic patterns: Processes shaping the microbial landscape. Nat. Rev. Microbiol. 2012, 10, 497-506. [CrossRef] [PubMed]

143. Tamames, J.; Abellan, J.J.; Pignatelli, M.; Camacho, A.; Moya, A. Environmental distribution of prokaryotic taxa. BMC Microbiol. 2010, 10, 85. [CrossRef] [PubMed]

144. Hahn, M.W.; Koll, U.; Jezberová, J.; Camacho, A. Global phylogeography of pelagic Polynucleobacter bacteria: Restricted geographic distribution of subgroups, isolation by distance and influence of climate. Environ. Microbiol. 2015, 17, 829-840. [CrossRef] [PubMed]

145. Huang, S.; Liu, Y.; Hu, A.; Liu, X.; Chen, F.; Yao, T. Genetic diversity of picocyanobacteria in Tibetan lakes: Assessing the endemic and universal distributions. Appl. Environ. Microbiol. 2014, 80, 7640-7650. [CrossRef] [PubMed]

146. Oda, Y.; Star, B.; Huisman, L.A. Biogeography of the purple nonsulfur bacterium Rhodopseudomonas palustris. Appl. Environ. Microbiol. 2003, 69, 5186-5191. [CrossRef] [PubMed]

147. Whitaker, R.J.; Grogan, D.W.; Taylor, J.W. Geographic barriers isolate endemic populations of hyperthermophilic archaea. Science 2003, 301, 976-978. [CrossRef] [PubMed]

148. Cho, J.-C.; Tiedje, J.M. Biogeography and degree of endemicity of fluorescent Pseudomonas strains in soil. Appl. Environ. Microbiol. 2000, 66, 5448-5456. [CrossRef] [PubMed]

149. van Tol, H.M.; Amin, S.A.; Armbrust, E.V. Ubiquitous marine bacterium inhibits diatom cell division. ISME J. 2017, 11, 31-42. [CrossRef] [PubMed]

150. Schneiker, S.; Santos, V.A.P.M.; Bartels, D.; Bekel, T.; Brecht, M.; Buhrmester, J.; Chernikova, T.N.; Denaro, R.; Ferrer, M.; Gertler, C.; et al. Genome sequence of the ubiquitous hydrocarbon-degrading marine bacterium Alcanivorax borkumensis. Nat. Biotechnol. 2006, 24, 997-1004. [CrossRef] [PubMed]

151. Rappé, M.S.; Connon, S.A.; Vergin, K.L.; Giovannoni, S.J. Cultivation of the ubiquitous SAR11 marine bacterioplankton clade. Nature 2002, 418, 630-633. [CrossRef] [PubMed]

152. Noguez, A.M.; Arita, H.T.; Escalente, A.E.; Forney, L.J.; García-Oliva, F.; Souza, V. Microbial macroecology: Highly structured prokaryotic soil assemblages in a tropical deciduous forest. Glob. Ecol. Biogeogr. 2005, 14, 241-248. [CrossRef]

153. Garcia, S.L. Mixed cultures as model communities: Hunting for ubiquitous microorganisms, their partners, and interactions. Aquat. Microb. Ecol. 2016, 77, 79-85. [CrossRef]

154. Mendes, R.; Garbeva, P.; Raaijmakers, J.M. The rhizosphere microbiome: Significance of plant beneficial, plant pathogenic, and human pathogenic microorganisms. FEMS Microbiol. Rev. 2013, 37, 634-663. [CrossRef] [PubMed]

155. Ward, B.B. How many species of prokaryotes are there? Proc. Natl. Acad. Sci. USA 2002, 99, 10234-10236. [CrossRef] [PubMed]

156. Lewis, K. Platforms for antibiotic discovery. Nat. Rev. Drug Discov. 2013, 12, 371-387. [CrossRef] [PubMed]

157. Ling, L.L.; Schneider, T.; Peoples, A.J.; Spoering, A.L.; Engels, I.; Conlon, B.P.; Mueller, A.; Schäberle, T.F.; Hughes, D.E.; Epstein, S.; et al. A new antibiotic kills pathogens without detectable resistance. Nature 2015, 517, 455-459. [CrossRef] [PubMed]

158. Logares, R.; Lindström, E.S.; Langenheder, S.; Logue, J.B.; Paterson, H.; Laybourn-Parry, J.; Rengefors, K.; Tranvik, L.; Bertilsson, S. Biogeography of bacterial communities exposed to progressive long-term environmental change. ISME J. 2013, 7, 937-948. [CrossRef] [PubMed] 
159. Juutilainen, K.; Mönkkönen, M.; Kotiranta, H.; Halme, P. Resource use of wood-inhabiting fungi in different boreal forest types. Fungal Ecol. 2017, 27, 96-106. [CrossRef]

160. Kassen, R. The experimental evolution of specialists, generalists, and the maintenance of diversity. J. Evol. Biol. 2002, 15, 173-190. [CrossRef]

161. Comte, J.; Lindström, E.S.; Eiler, A.; Langenheder, S. Can marine bacteria be recruited from freshwater sources and the air? ISME J. 2014, 8, 2423-2430. [CrossRef] [PubMed]

162. Wehner, J.; Mittelbach, M.; Rillig, M.C.; Verbruggen, E. Specialist nectar-yeasts decline with urbanization in Berlin. Sci. Rep. 2017, 7, 45315. [CrossRef] [PubMed]

163. Székely, A.J.; Langenheder, S. The importance of species sorting differs between habitat generalists and specialists in bacterial communities. FEMS Microbiol. Ecol. 2014, 87, 102-112. [CrossRef] [PubMed]

164. Székely, A.J.; Berga, M.; Langenheder, S. Mechanisms determining the fate of dispersed bacterial communities in new environments. ISME J. 2013, 7, 61-71. [CrossRef] [PubMed]

165. Ishida, T.A.; Nara, K.; Hogetsu, T. Host effects on ectomycorrhizal fungal communities: Insight from eight host species in mixed conifer-broadleaf forests. New Phytol. 2007, 174, 430-440. [CrossRef] [PubMed]

166. Kernaghan, G.; Patriquin, G. Host associations between fungal root endophytes and boreal trees. Microb. Ecol. 2011, 62, 460-473. [CrossRef] [PubMed]

167. Tedersoo, L.; Mett, M.; Ishida, T.A.; Bahram, M. Phylogenetic relationships among host plants explain differences in fungal species richness and community composition in ectomycorrhizal symbiosis. New Phytol. 2013, 199, 822-831. [CrossRef] [PubMed]

168. Bálint, M.; Bartha, L.; O’Hara, R.; Olson, M.S.; Otte, J.; Pfenninger, M.; Pfenninger, M.; Robertson, A.L.; Tiffin, P.; Schmitt, I. Relocation, high-latitude warming and host genetic identity shape the foliar fungal microbiome of poplars. Mol. Ecol. 2015, 24, 235-248. [CrossRef] [PubMed]

169. Liu, X.; Liang, M.; Etienne, R.S.; Wang, Y.; Staehelin, C.; Yu, S. Experimental evidence for a phylogenetic Janzen-Connell effect in a subtropical forest. Ecol. Lett. 2011, 15, 111-118. [CrossRef] [PubMed]

170. Daniell, T.J.; Husband, R.; Fitter, A.H.; Young, J.P.W. Molecular diversity of arbuscular mycorrhizal fungi colonising arable crops. FEMS Microbiol. Ecol. 2001, 36, 203-209. [CrossRef] [PubMed]

171. Vandenkoornhuyse, P.; Husband, R.; Daniell, T.J.; Watson, I.J.; Duck, J.M.; Fitter, A.H.; Young, J.P. Arbuscular mycorrhizal community composition associated with two plant species in a grassland ecosystem. Mol. Ecol. 2002, 11, 1555-1564. [CrossRef] [PubMed]

172. Elster, J.; Margesin, R.; Wagner, D.; Häggblom, M. Editorial: Polar and Alpine Microbiology-Earth's cryobiosphere. FEMS Microbiol. Ecol. 2017, 93, fiw221. [CrossRef] [PubMed]

173. Aliyu, H.; De Maayer, P.; Cowan, D. The genome of the Antarctic polyextremophile Nesterenkonia sp. AN1 reveals adaptive strategies for survival under multiple stress conditions. FEMS Microbiol. Ecol. 2016, 92, fiw032. [CrossRef] [PubMed]

174. Goordial, J.; Raymond-Bouchard, I.; Zolotarov, Y.; de Bethencourt, L.; Ronholm, J.; Shapiro, N.; Woyke, T.; Stromvik, M.; Greer, C.W.; Bakermans, C.; et al. Cold adaptive traits revealed by comparative genomic analysis of the eurypsychrophile Rhodococcus sp. JG3 isolated from high elevation McMurdo Dry Valley permafrost, Antarctica. FEMS Microbiol. Ecol. 2016, 92, fiv154. [CrossRef] [PubMed]

175. Petrovskaya, L.E.; Novotoskaya-Vlasova, K.A.; Spirina, E.V.; Durdenko, E.V.; Lomakina, G.Y.; Zavialova, M.G.; Nikolaev, E.N.; Rivkina, E.M. Expression and characterization of a new esterase with GCSAG motif from a permafrost metagenomic library. FEMS Microbiol. Ecol. 2016, 92, fiw046. [CrossRef] [PubMed]

176. Ciok, A.; Dziewit, L.; Grzesiak, J.; Budzik, K.; Gorniak, D.; Zdanowski, M.K.; Bartosik, D. Identification of miniature plasmids in psychrophilic Arctic bacteria of the genus Variovorax. FEMS Microbiol. Ecol. 2016, 92, fiw043. [CrossRef] [PubMed]

177. Baulina, O.; Gorelova, O.; Solovchenko, A.; Chivkunova, O.; Semenova, L.; Selyakh, I.; Scherbakov, P.; Burakova, O.; Lobakova, E. Diversity of the nitrogen starvation responses in subarctic Desmodesmus sp. (Chlorophyceae) strains isolated from symbioses with invertebrates. FEMS Microbiol. Ecol. 2016, 92, fiw031. [CrossRef] [PubMed]

178. Herburger, K.; Remias, D.; Holzinger, A. The green alga Zygogonium ericetorum (Zygnematophyceae, Charophyta) shows high iron and aluminium tolerance: Protection mechanisms and photosynthetic performance. FEMS Microbiol. Ecol. 2016, 92, fiw103. [CrossRef] [PubMed] 
179. Remias, D.; Pichrtová, M.; Pangratz, M.; Lütz, C.; Holzinger, A. Ecophysiology, secondary pigments and ultrastructure of Chlainomonas sp. (Chlorophyta) from the European Alps compared with Chlamydomonas nivalis forming red snow. FEMS Microbiol. Ecol. 2016, 92, fiw030. [CrossRef] [PubMed]

180. Colangelo-Lillis, J.; Eicken, H.; Carpenter, S.D.; Deming, J.W. Evidence for marine origin and microbial-viral habitability of sub-zero hypersaline aqueous inclusions within permafrost near Barrow, Alaska. FEMS Microbiol. Ecol. 2016, 92, fiw053. [CrossRef] [PubMed]

181. de Cárcer, D.A.; López-Bueno, A.; Alonso-Lobo, J.M.; Quesada, A.; Alcamí, A. Metagenomic analysis of lacustrine viral diversity along a latitudinal transect of the Antarctic Peninsula. FEMS Microbiol. Ecol. 2016, 92, fiw074. [CrossRef] [PubMed]

182. Amin, A.; Ahmed, I.; Salam, N.; Kim, B.-Y.; Singh, D.; Zhi, X.-Y.; Xiao, M.; Li, W.J. Diversity and distribution of thermophilic bacteria in hot springs of Pakistan. Microb. Ecol. 2017, 74, 116-127. [CrossRef] [PubMed]

183. Wang, S.; Hou, W.; Dong, H.; Jiang, H.; Huang, L.; Wu, G.; Zhang, C.; Song, Z.; Zhang, Y.; Ren, H.; et al. Control of temperature on microbial community structure in hot springs of the Tibetan plateau. PLOS ONE 2013, 8, e62901. [CrossRef] [PubMed]

184. Kubo, K.; Knittel, K.; Amann, R.; Fukui, M.; Matsuura, K. Sulfur-metabolizing bacterial populations in microbial mats of the Nakabusa hot spring, Japan. Syst. Appl. Microbiol. 2011, 34, 293-302. [CrossRef] [PubMed]

185. Bohorquez, L.C.; Delgado-Serrano, L.; Lopez, G.; Osorio-Forero, C.; Klepac-Ceraj, V.; Kolter, R.; Junca, H.; Baena, S.; Zambrano, M.M. In-depth characterization via complementing culture-independent approaches of microbial community in an acidic hot spring of the Colombian Andes. Microb. Ecol. 2012, 63, 103-115. [CrossRef] [PubMed]

186. Kanoksilapatham, W.; Pasomsup, P.; Keawram, P.; Cuecas, A.; Portillo, M.C.; Gonzalez, J.M. Fervidobacterium thailandense sp. nov., an extremely thermophilic bacterium isolated from a hot spring. Int. J. Syst. Evol. Microbiol. 2016, 66, 5023-5027. [CrossRef] [PubMed]

187. Ming, H.; Duan, Y.-Y.; Yin, Y.-R.; Meng, X.-L.; Li, S.; Zhou, E.-M.; Huang, J.R.; Nie, G.X.; Li, W.J. Crenalkalicoccus roseus gen. nov., sp. nov., a thermophilic bacterium isolated from alkaline hot springs. Int. J. Syst. Evol. Microbiol. 2016, 66, 2319-2326. [CrossRef] [PubMed]

188. Priya, I.; Dhar, M.K.; Bajaj, B.K.; Koul, S.; Vakhlu, J. Cellulolytic activity of thermophilic bacilli isolated from Tattapani hot spring sediment in north west Himalayas. Indian J. Microbiol. 2016, 56, 228-231. [CrossRef] [PubMed]

189. Tank, M.; Thiel, V.; Ward, D.M.; Bryant, D.A. A panoply of phototrophs: An overview of the thermophilic chlorophototrophs of the microbial mats of alkaline siliceous hot springs in Yellowstone national park, WY, USA. In Modern Topics in the Phototrophic Prokaryotes; Hallenbeck, P.C., Ed.; Springer: Cham, Switzerland, 2017; pp. 87-137. [CrossRef]

190. Tazi, L.; Breakwell, D.P.; Harker, A.R.; Crandall, K.A. Life in extreme environments: Microbial diversity in Great Salt Lake, Utah. Extremophiles 2014, 18, 525-535. [CrossRef] [PubMed]

191. Abdallah, M.B.; Karray, F.; Mhiri, N.; Mei, N.; Quéméneur, M.; Cayol, J.-L.; Erauso, G.; Tholozan, J.L.; Alazard, D.; Sayadi, S. Prokaryotic diversity in a Tunisian hypersaline lake, Chott El Jerid. Extremophiles 2016, 20, 125-138. [CrossRef] [PubMed]

192. Khalilova, E.A.; Kotenko, S.T.; Islammagomedova, E.A.; Gasanov, R.Z.; Abakarova, A.A.; Aliverdieva, D.A. Extremophilic microbial communities of saline soils and their diversity in the regions of the Caspian Depression. Arid Ecosyst. 2017, 7, 116-120. [CrossRef]

193. Zhang, L.; Wang, Y.; Liang, J.; Song, Q.; Zhang, X.-H. Degradation properties of various macromolecules of culturable psychrophilic bacteria from the deep-sea water of the South Pacific Gyre. Extremophiles 2016, 20, 663-671. [CrossRef] [PubMed]

194. Pathom-aree, W.; Stach, J.E.M.; Ward, A.C.; Horikoshi, K.; Bull, A.T.; Goodfellow, M. Diversity of actinomycetes isolated from Challenger Deep sediment $(10,898 \mathrm{~m})$ from the Mariana Trench. Extremophiles 2006, 10, 181-189. [CrossRef] [PubMed]

195. Jebbar, M. Deep sea, the last great unexplored Earth frontier harboring the largest unknown and untapped remote microbial diversity on our planet. Res. Microbiol. 2015, 166, 665-667. [CrossRef] [PubMed]

196. Lauro, F.M.; Bartlett, D.H. Prokaryotic lifestyles in deep sea habitats. Extremophiles 2008, 12, 15-25. [CrossRef] [PubMed] 
197. Musilova, M.; Wright, G.; Ward, J.M.; Dartnell, L.R. Isolation of radiation-resistant bacteria from mars analog Antarctic dry valleys by preselection, and the correlation between radiation and desiccation resistance. Astrobiology 2015, 15, 1076-1090. [CrossRef] [PubMed]

198. Albarracín, V.H.; Simon, J.; Pathak, G.P.; Valle, L.; Douki, T.; Cadet, J.; Borsarelli, C.D.; Farias, M.E.; Gärtner, W. First characterisation of a CPD-class I photolyase from a UV-resistant extremophile isolated from High-Altitude Andean Lakes. Photochem. Photobiol. Sci. 2014, 13, 739-750. [CrossRef] [PubMed]

199. Morozova, D.; Moeller, R.; Rettberg, P.; Wagner, D. Enhanced radiation resistance of Methanosarcina soligelidi SMA-21, a new methanogenic archaeon isolated from a siberian permafrost-affected soil in direct comparison to Methanosarcina barkeri. Astrobiology 2015, 15, 951-960. [CrossRef] [PubMed]

200. Rao, S.; Chan, O.W.; Lacap-Bugler, D.C.; Pointing, S.B. Radiation-tolerant bacteria isolated from high altitude soil in Tibet. Indian J. Microbiol. 2016, 56, 508-512. [CrossRef] [PubMed]

201. Krisko, A.; Radman, M. Biology of Extreme Radiation Resistance: The Way of Deinococcus radiodurans. Cold Spring Harb. Perspect. Biol. 2013, 5, a012765. [CrossRef] [PubMed]

202. Vitorino, L.C.; Bessa, L.A. Technological microbiology: Development and applications. Front. Microbiol. 2017, 8, 827. [CrossRef] [PubMed]

203. Vlasova, A.N.; Kandasamy, S.; Chattha, K.S.; Rajashekara, G.; Saif, L.J. Comparison of probiotic lactobacilli and bifidobacteria effects, immune responses and rotavirus vaccines and infection in different host species. Vet. Immunol. Immunopathol. 2016, 172, 72-84. [CrossRef] [PubMed]

204. Allen, S.J.; Warehan, K.; Wang, D.; Bradley, C.; Hutchings, H.; Harris, W.; Dhar, A.; Brown, H.; Foden, A.; Gravenor, M.B.; et al. Lactobacilli and bifidobacteria in the prevention of antibiotic-associated diarrhoea and Clostridium difficile diarrhoea in older inpatients (PLACIDE): A randomised, double-blind, placebo-controlled, multicentre trial. Lancet 2013, 1249-1257. [CrossRef]

205. Wang, L.; Zhang, J.; Guo, Z.; Kwok, L.; Ma, C.; Zhang, W.; Lv, Q.; Huang, W.; Zhang, H. Effect of oral consumption of probiotic Lactobacillus planatarum P-8 on fecal microbiota, SIgA, SCFAs, and TBAs of adults of different ages. Nutrition 2014, 30, 776-783.e1. [CrossRef] [PubMed]

206. Al-Otaibi, H.S.; Gashgari, R.M.; Mohammed, A.E.; Almojel, A.S.; Elobeid, M.M.; Abrahaim, J.S.A. Investigation of the growth ability of probiotic (Lactobacillus and Bifidobacterium) in infant's milk under different environmental conditions. Biomed. Pharmacol. J. 2016, 9, 451-462. [CrossRef]

207. Lodemann, U.; Strahlendorf, J.; Schierack, P.; Klingspor, S.; Aschenbach, J.R. Effects of the probiotic Enterococcus faecium and pathogenic Escherichia coli strains in a pig and human epithelial intestinal cell model. Scientifica 2015, 235184. [CrossRef]

208. Koruri, S.S.; Chowdhury, R.; Bhattacharya, P. Potentiation os functional and antimicrobial activities through synergistic growth of probiotic Pediococcus acidilactici with natural prebiotics (garlic, basil). In Microbes in the Spotlight: Recent Progress in the Understanding of Beneficial and Harmful Microorganisms; Méndez-Vilas, A., Ed.; BrownWalker Press: Boca Raton, FL, USA, 2016; pp. 219-224.

209. Kandylis, P.; Pissaridi, K.; Bekatorou, A.; Kanellaki, M.; Koutinas, A.A. Dairy and non-dairy probiotic beverages. Curr. Opin. Food Sci. 2016, 7, 58-63. [CrossRef]

210. Adejuwon, A.O.; Oluduro, A.O.; Agboola, F.K.; Olutiola, P.O.; Burkhardt, B.A.; Segal, S.J. Expression of $\alpha$-amylase by Aspergillus niger: Effect of nitrogen source of growth medium. Adv. Biosci. Bioeng. 2015, 3, 12-19.

211. Ploss, T.N.; Reilman, E.; Monteferrante, C.G.; Denham, E.L.; Piersma, S.; Lingner, A.; Vehmaanperä, J.; Lorenz, P.; DijlEmail, J.M. Homogeneity and heterogeneity in amylase production by Bacillus subtilis under different growth conditions. Microb. Cell Fact. 2016, 15, 1-16. [CrossRef] [PubMed]

212. Bueno, M.M.; Thys, R.C.S.; Rodrigues, R.C. Microbial enzymes as substitutes of chemical additives in baking wheat flour-part II: Combined effects of nine enzymes on dough rheology. Food Bioprocess Tech. 2016, 9, 1598-1611. [CrossRef]

213. Reginatto, C.; Rossi, C.; Miglioranza, B.G.; Santos, M.; Meneghel, L.; Silveira, M.M.; Malvessi, E. Pectinase production by Aspergillus niger LB-02-SF is influenced by the culture medium composition and the addition of the enzyme inducer after biomass growth. Process Biochem. 2017, 58, 1-8. [CrossRef]

214. Kalac, P. Edible Mushrooms: Chemical Composition and Nutritional Value; Academic Press: Oxford, UK, $2016 ; 236$ p.

215. Cruz, A.; Pimentel, L.; Rodríguez-Alcalá, R.; Fernandes, T.; Pintado, M. Health benefits of edible mushrooms focused on Coriolus versicolor: A review. J. Food Nutr. Res. 2016, 4, 773-781. [CrossRef] 
216. Chang, R. Functional properties of edible mushrooms. Nutr. Rev. 1996, 54, S91-S93. [CrossRef] [PubMed]

217. Anupama, R.P. Value-added food: Single cell protein. Biotechnol. Adv. 2000, 18, 459-479. [CrossRef]

218. Matassa, S.; Boon, N.; Pikaar, I.; Verstraete, W. Microbial protein: Future sustainable food supply route with low environmental footprint. Microb. Biotechnol. 2016, 9, 568-575. [CrossRef] [PubMed]

219. Nalage, D.N.; Khedkar, G.D.; Kalyankar, A.D.; Sarkate, A.P.; Ghodke, S.R.; Bedre, V.B. Single cell proteins. In The Encyclopedia of Food and Health; Caballero, B., Finglas, P., Toldrá, F., Eds.; Academic Press: Oxford, UK, 2016; pp. 790-794. [CrossRef]

220. Borghesi, A.; Stronati, M. Superbugs and antibiotics in the newborn. J. Pediatr. Neonat. Individ. Med. 2015, 4, e040253. [CrossRef]

221. Adrio, J.L.; Demain, A.L. Microbial enzymes: Tools for biotechnological processes. Biomolecules 2014, 4, 117-139. [CrossRef] [PubMed]

222. Mishra, S.S.; Ray, R.C.; Rosell, C.M.; Panda, D. Microbial enzymes in food applications-history of progress. In Microbial Enzyme Technology in Food Applications; Ray, R.C., Rossell, C.M., Eds.; CRC Press: Boca Raton, FL, USA, 2016; pp. 3-18.

223. Aehle, W. Enzymes in Industry: Production and Applications; Wiley-VCH Verlag GmbH \& Co. KGaA: Weinheim, Germany, 2007; 516p.

224. Panda, S.K.; Mishra, S.S.; Kayitesi, E.; Ray, R.C. Microbial-processing of fruit and vegetable wastes for production of vital enzymes and organic acids: Biotechnology and scopes. Environ. Res. 2016, 146, 161-172. [CrossRef] [PubMed]

225. Berrio-Restrepo, J.M.; Saldarriaga, J.C.; Correa, M.A.; Aguirre, N.J. Extracellular enzymatic activity of two hydrolases in wastewater treatment for biological nutrient removal. Appl. Microbiol. Biotechnol. 2017, 101, 7385-7396. [CrossRef] [PubMed]

226. Kreutz, J.A.; Böckenhüser, I.; Wacht, M.; Fischer, K. A 1-year study of the activities of seven hydrolases in a communal wastewater treatment plant: Trends and correlations. Appl. Microbiol. Biotechnol. 2016, 100, 6903-6915. [CrossRef] [PubMed]

227. Hasan, F.; Shah, A.A.; Hameed, A. Industrial applications of microbial lipases. Enzyme Microb. Technol. 2006, 39, 235-251. [CrossRef]

228. Jones, E.E.; Bienkowski, D.A.; Stewart, A. The importance of water potential range tolerance as a limiting factor on Trichoderma spp. biocontrol of Sclerotinia sclerotiorum. Ann. Appl. Biol. 2016, 168, 41-51. [CrossRef]

229. Jones, E.E.; Rabeendran, N.; Stewart, A. Biocontrol of Sclerotinia sclerotiorum infection of cabbage by C. minitans and Trichoderma spp. Biocontrol. Sci. Technol. 2014, 24, 1363-1382. [CrossRef]

230. Saravanakumar, K.; Yu, C.; Dou, K.; Wang, M.; Li, Y.; Chen, J. Synergistic effect of Trichoderma-derived antifungal metabolites and cell wall degrading enzymes on enhanced biocontrol of Fusarium oxysporum $\mathrm{f}$. sp. cucumerinum. Biol. Control 2016, 94, 37-46. [CrossRef]

231. Carrero-Carrón, I.; Trapero-Casas, J.L.; Olivares-García, C.; Monte, E.; Hermosa, R.; Jiménez-Díaz, R.M. Trichoderma asperellum is effective for biocontrol of Verticillium wilt in olive caused by the defoliating pathotype of Verticillium dahlia. Crop Prot. 2016, 88, 45-52. [CrossRef]

232. Khaledi, N.; Taheri, P. Biocontrol mechanisms of Trichoderma harzianum against soybean charcoal rot caused by Macrophomina phaseolina. J. Plant Prot. Res. 2016, 56, 21-31. [CrossRef]

233. Sokhandani, Z.; Moosavi, M.R.; Basirnia, T. Optimum concentrations of Trichoderma longibrachiatum and cadusafos for controlling Meloidogyne javanica on Zucchini plants. J. Nematol. 2016, 48, 54-63. [CrossRef] [PubMed]

234. Feyisa, B.; Lencho, A.; Selvaraj, T.; Getaneh, G. Evaluation of some botanicals and Trichoderma harzianum against root-knot nematode (Meloidogyne incognita (Kofoid and White) Chit wood) in tomato. J. Entomol. Nematol. 2016, 8, 11-18. [CrossRef]

235. Sahebani, N.; Hadavi, N. Biological control of the root-knot nematode Meloidogyne javanica by Trichoderma harzianum. Soil Biol. Biochem. 2008, 40, 2016-2020. [CrossRef]

236. Kuan, K.B.; Othman, R.; Rahim, K.A.; Shamsuddin, Z.H. Plant growth-promoting rhizobacteria inoculation to enhance vegetative growth, nitrogen fixation and nitrogen remobilisation of maize under greenhouse conditions. PLoS ONE 2016, 11, e0152478. [CrossRef] [PubMed]

237. Puri, A.; Padda, K.P.; Chanway, C.P. Evidence of nitrogen fixation and growth promotion in canola (Brassica napus L.) by an endophytic diazotroph Paenibacillus polymyxa P2b-2R. Biol. Fert. Soils 2016, 52, 119-125. [CrossRef] 
238. Spaepen, S. Plant hormones produced by microbes. In Principles of Plant-Microbe Interactions; Lugtenberg, B., Ed.; Springer: Cham, Switzerland, 2015; pp. 247-256.

239. Ahmad, S.; Abbas, S.S.; Prakash, R.; Alam, A.; Husain, M.A. Applications of endophytic Actinomycetes and their role in protection. Imp. J. Interdiscip. Res. 2016, 1-2, 854-858.

240. Kumar, A.; Bahadur, I.; Maurya, B.R.; Raghuwanshi, R.; Meena, V.S.; Singh, D.K. Does a plant growth promoting rhizobacteria enhance agricultural sustainability? J. Pure Appl. Microbiol. 2015, 9, 715-724.

241. Awadhiya, A.; Tyeb, S.; Rathore, K.; Verma, V. Agarose bioplastic-based drug delivery system for surgical and wound dressings. Eng. Life Sci. 2016, 17, 204-214. [CrossRef]

242. Ivanov, V.; Stabnikov, V. Construction biotechnological plastics. In Construction Biotechnology; Ivanov, V., Stabnikov, V., Eds.; Springer: Singapore, 2017; pp. 51-75.

243. Blackwell, M. The fungi: 1, 2, 3 . . 5.1 million species? Am. J. Bot. 2011, 98, 426-438. [CrossRef] [PubMed]

C 2018 by the authors. Licensee MDPI, Basel, Switzerland. This article is an open access article distributed under the terms and conditions of the Creative Commons Attribution (CC BY) license (http://creativecommons.org/licenses/by/4.0/). 